\title{
LEVEL II SCOUR ANALYSIS FOR BRIDGE 43 (CHELTH00460043) on TOWN HIGHWAY 46, crossing JAIL BROOK, CHELSEA, VERMONT
}

U.S. Geological Survey Open-File Report 97-386

Prepared in cooperation with

VERMONT AGENCY OF TRANSPORTATION and

FEDERAL HIGHWAY ADMINISTRATION 


\section{LEVEL II SCOUR ANALYSIS FOR BRIDGE 43 (CHELTH00460043) on TOWN HIGHWAY 46, crossing JAIL BROOK, CHELSEA, VERMONT By SCOTT A. OLSON}

U.S. Geological Survey Open-File Report 97-386

Prepared in cooperation with

VERMONT AGENCY OF TRANSPORTATION and

FEDERAL HIGHWAY ADMINISTRATION 


\title{
U.S. DEPARTMENT OF THE INTERIOR BRUCE BABBITT, Secretary
}

\author{
U.S. GEOLOGICAL SURVEY \\ Gordon P. Eaton, Director
}

For additional information write to:

District Chief

U.S. Geological Survey 361 Commerce Way

Pembroke, NH 03275-3718
Copies of this report may be purchased from:

U.S. Geological Survey

Branch of Information Services

Open-File Reports Unit

Box 25286

Denver, CO 80225-0286 


\section{CONTENTS}

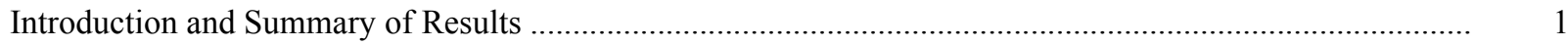

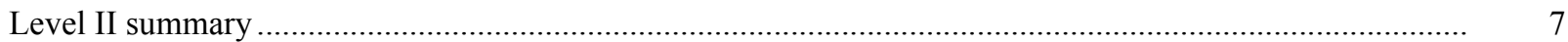

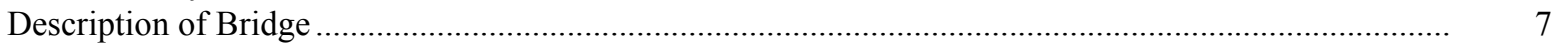

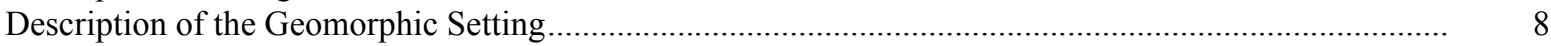

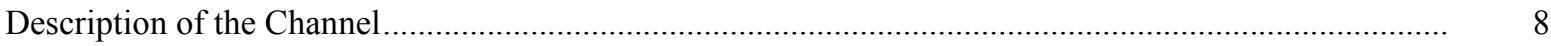

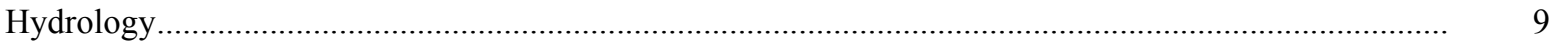

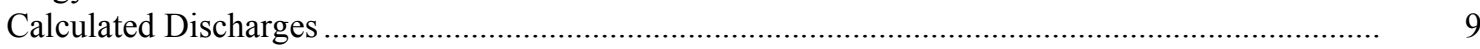

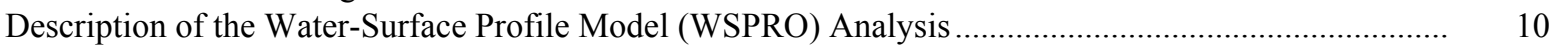

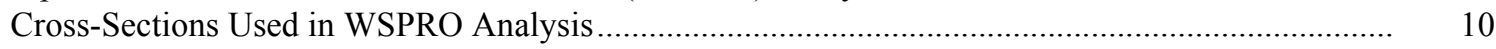

Data and Assumptions Used in WSPRO Model ..................................................................... 11

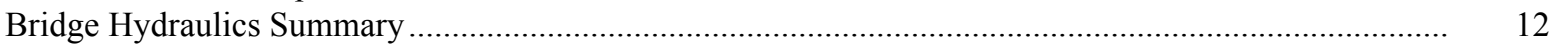

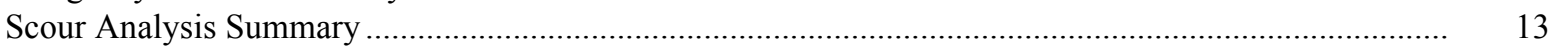

Special Conditions or Assumptions Made in Scour Analysis ...................................................... 13

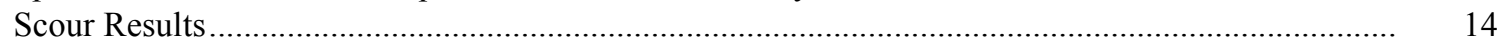

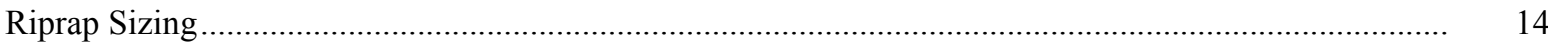

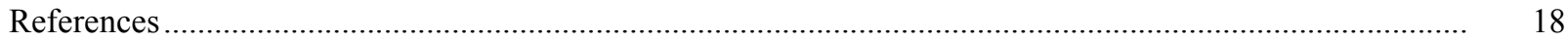

Appendixes:

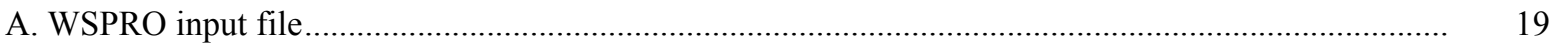

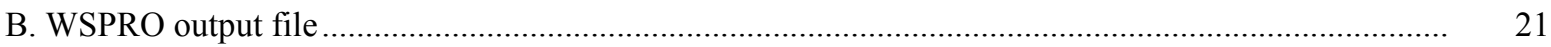

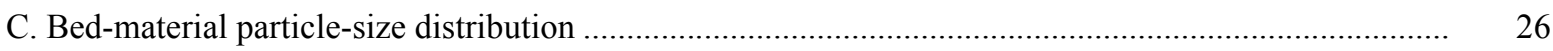

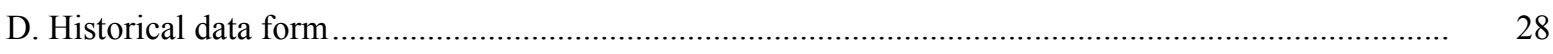

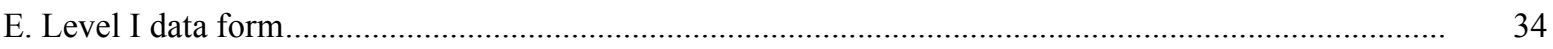

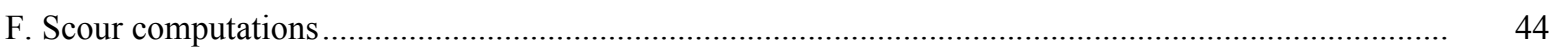

\section{FIGURES}

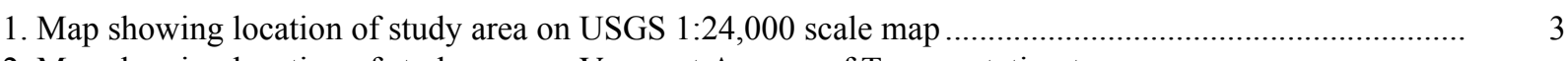

2. Map showing location of study area on Vermont Agency of Transportation town

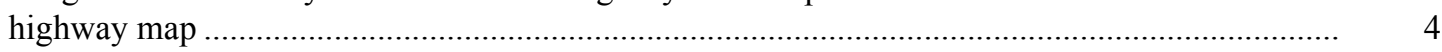

3. Structure CHELTH00460043 viewed from upstream (November 18, 1994) ........................................... 5

4. Downstream channel viewed from structure CHELTH00460043 (November 18, 1994), ....................... 5

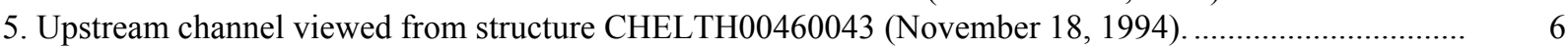

6. Structure CHELTH00460043 viewed from downstream (November 18, 1994)................................... 6

7. Water-surface profiles for the 100- and 500-year discharges at structure

CHELTH00460043 on Town Highway 46, crossing Jail Brook,

Chelsea, Vermont.

8. Scour elevations for the 100- and 500-year discharges at structure

CHELTH00460043 on Town Highway 46, crossing Jail Brook,

Chelsea, Vermont.

\section{TABLES}

1. Remaining footing/pile depth at abutments for the 100-year discharge at structure

CHELTH00460043 on Town Highway 46, crossing Jail Brook,

Chelsea, Vermont.

2. Remaining footing/pile depth at abutments for the 500-year discharge at structure

CHELTH00460043 on Town Highway 46, crossing Jail Brook,

Chelsea, Vermont. 


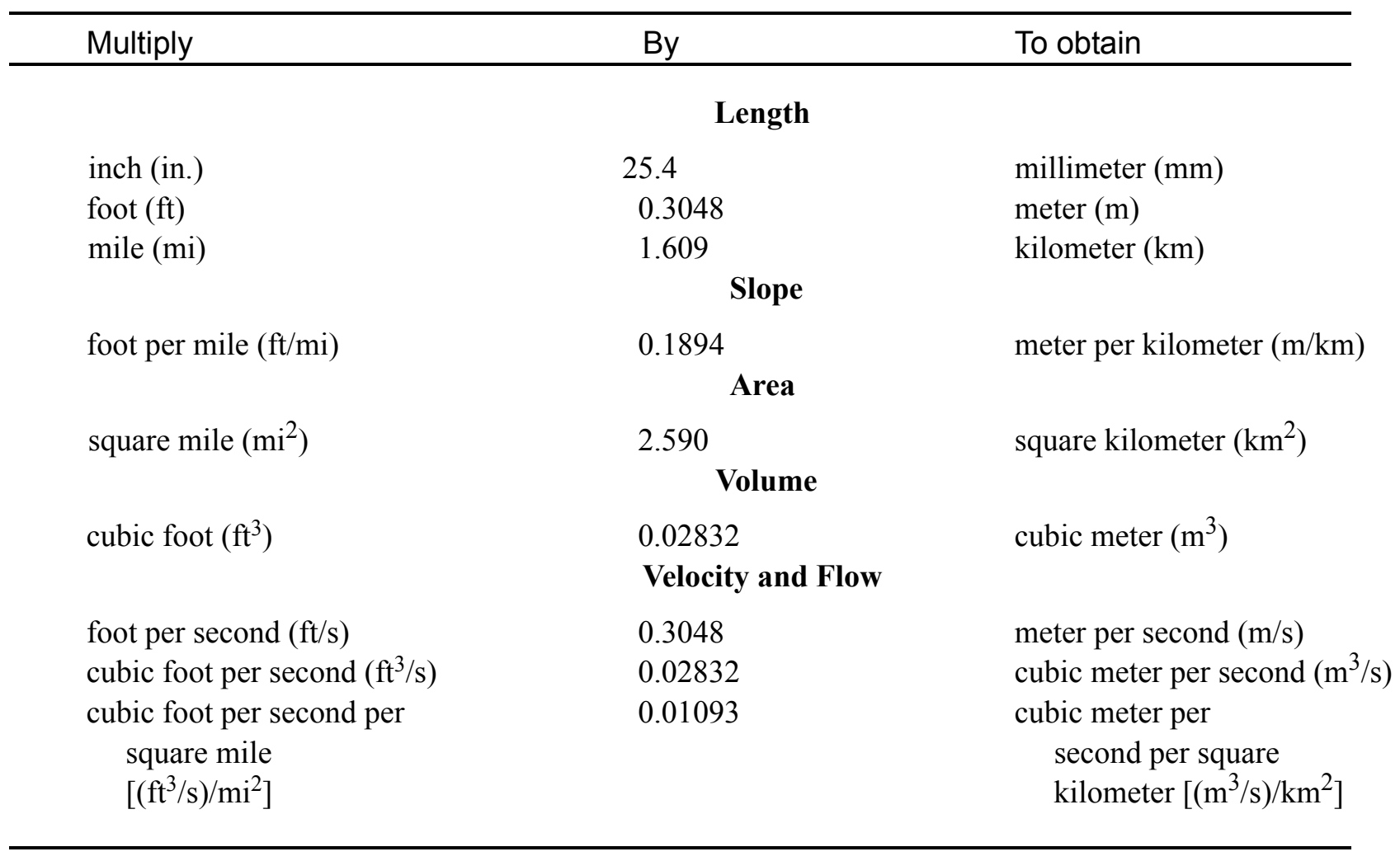

\section{OTHER ABBREVIATIONS}

$\begin{array}{lrlr}\mathrm{BF} & \text { bank full } & \text { LWW } & \text { left wingwall } \\ \mathrm{cfs} & \text { cubic feet per second } & \text { MC } & \text { main channel } \\ \mathrm{D}_{50} & \text { median diameter of bed material } & \text { RAB } & \text { right abutment } \\ \mathrm{DS} & \text { downstream } & \text { RABUT } & \text { face of right abutment } \\ \mathrm{elev} & \text { elevation } & \text { RB } & \text { right bank } \\ \mathrm{f} / \mathrm{p} & \text { flood plain } & \text { ROB } & \text { right overbank } \\ \mathrm{ft}^{2} & \text { square feet } & \text { RWW } & \text { right wingwall } \\ \mathrm{ft} / \mathrm{ft} & \text { feet per foot } & \text { TH } & \text { town highway } \\ \mathrm{JCT} & \text { junction } & \text { UB } & \text { under bridge } \\ \mathrm{LAB} & \text { left abutment } & \text { US } & \text { upstream } \\ \mathrm{LABUT} & \text { face of left abutment } & \text { USGS } & \text { United States Geological Survey } \\ \mathrm{LB} & \text { left bank } & \text { VTAOT Vermont Agency of Transportation } \\ \mathrm{LOB} & \text { left overbank } & \text { WSPRO } & \text { water-surface profile model }\end{array}$

In this report, the words "right" and "left" refer to directions that would be reported by an observer facing downstream. Sea level: In this report, "sea level" refers to the National Geodetic Vertical Datum of 1929-- a geodetic datum derived from a general adjustment of the first-order level nets of the United States and Canada, formerly called Sea Level Datum of 1929.

In the appendices, the above abbreviations may be combined. For example, USLB would represent upstream left bank. 


\title{
LEVEL II SCOUR ANALYSIS FOR BRIDGE 43 (CHELTH00460043) ON TOWN HIGHWAY 46, CROSSING JAIL BROOK, CHELSEA, VERMONT
}

\author{
By Scott A. Olson
}

\section{INTRODUCTION AND SUMMARY OF RESULTS}

This report provides the results of a detailed Level II analysis of scour potential at structure CHELTH00460043 on Town Highway 46 crossing Jail Brook, Chelsea, Vermont (figures 1-8). A Level II study is a basic engineering analysis of the site, including a quantitative analysis of stream stability and scour (U.S. Department of Transportation, 1993). Results of a Level I scour investigation also are included in Appendix E of this report. A Level I investigation provides a qualitative geomorphic characterization of the study site. Information on the bridge, gleaned from Vermont Agency of Transportation (VTAOT) files, was compiled prior to conducting Level I and Level II analyses and is found in Appendix D.

The site is in the New England Upland section of the New England physiographic province in central Vermont. The 4.68- $\mathrm{mi}^{2}$ drainage area is in a predominantly rural and forested basin. In the vicinity of the study site, the surface cover is best described as suburban with homes, lawns, and a few trees.

In the study area, Jail Brook has an incised, straight channel with a slope of approximately $0.02 \mathrm{ft} / \mathrm{ft}$, an average channel top width of $32 \mathrm{ft}$ and an average bank height of $6 \mathrm{ft}$. The channel bed material ranges from coarse sand to boulder with a median grain size $\left(\mathrm{D}_{50}\right)$ of $43.0 \mathrm{~mm}(0.141 \mathrm{ft})$. The geomorphic assessment at the time of the Level I and Level II site visit on November 18, 1994, indicated that the reach was stable.

The Town Highway 46 crossing of Jail Brook is a 27-ft-long, two-lane bridge consisting of one 23-foot concrete span (Vermont Agency of Transportation, written communication, August 25, 1994). The opening length of the structure parallel to the bridge face is 22.8 $\mathrm{ft}$. The bridge is supported by vertical, concrete abutments with wingwalls. The channel is skewed approximately zero degrees to the opening and the opening-skew-to-roadway is also zero degrees.

Channel scour was not observed. However, the left abutment footing was exposed one foot. Scour countermeasures at the site consisted of type- 2 stone fill (less than 36 inches diameter) on the banks and road embankments upstream and downstream of the bridge. Additional details describing conditions at the site are included in the Level II Summary and Appendices D and E. 
Scour depths and recommended rock rip-rap sizes were computed using the general guidelines described in Hydraulic Engineering Circular 18 (Richardson and others, 1995). Total scour at a highway crossing is comprised of three components: 1) long-term streambed degradation; 2) contraction scour (due to accelerated flow caused by a reduction in flow area at a bridge) and; 3 ) local scour (caused by accelerated flow around piers and abutments). Total scour is the sum of the three components. Equations are available to compute depths for contraction and local scour and a summary of the results of these computations follows.

Contraction scour for all modelled flows ranged from 1.1 to $1.2 \mathrm{ft}$. The worst-case contraction scour occurred at the 500-year discharge. Abutment scour ranged from 5.0 to $6.5 \mathrm{ft}$ at the left abutment and 4.7 to $6.2 \mathrm{ft}$ at the right abutment. The worst-case abutment scour occurred at the 500-year discharge. Additional information on scour depths and depths to armoring are included in the section titled "Scour Results". Scoured-streambed elevations, based on the calculated scour depths, are presented in tables 1 and 2. A crosssection of the scour computed at the bridge is presented in figure 8. Scour depths were calculated assuming an infinite depth of erosive material and a homogeneous particle-size distribution.

It is generally accepted that the Froehlich equation (abutment scour) gives "excessively conservative estimates of scour depths" (Richardson and others, 1995, p. 47). Usually, computed scour depths are evaluated in combination with other information including (but not limited to) historical performance during flood events, the geomorphic stability assessment, existing scour protection measures, and the results of the hydraulic analyses. Therefore, scour depths adopted by VTAOT may differ from the computed values documented herein. 


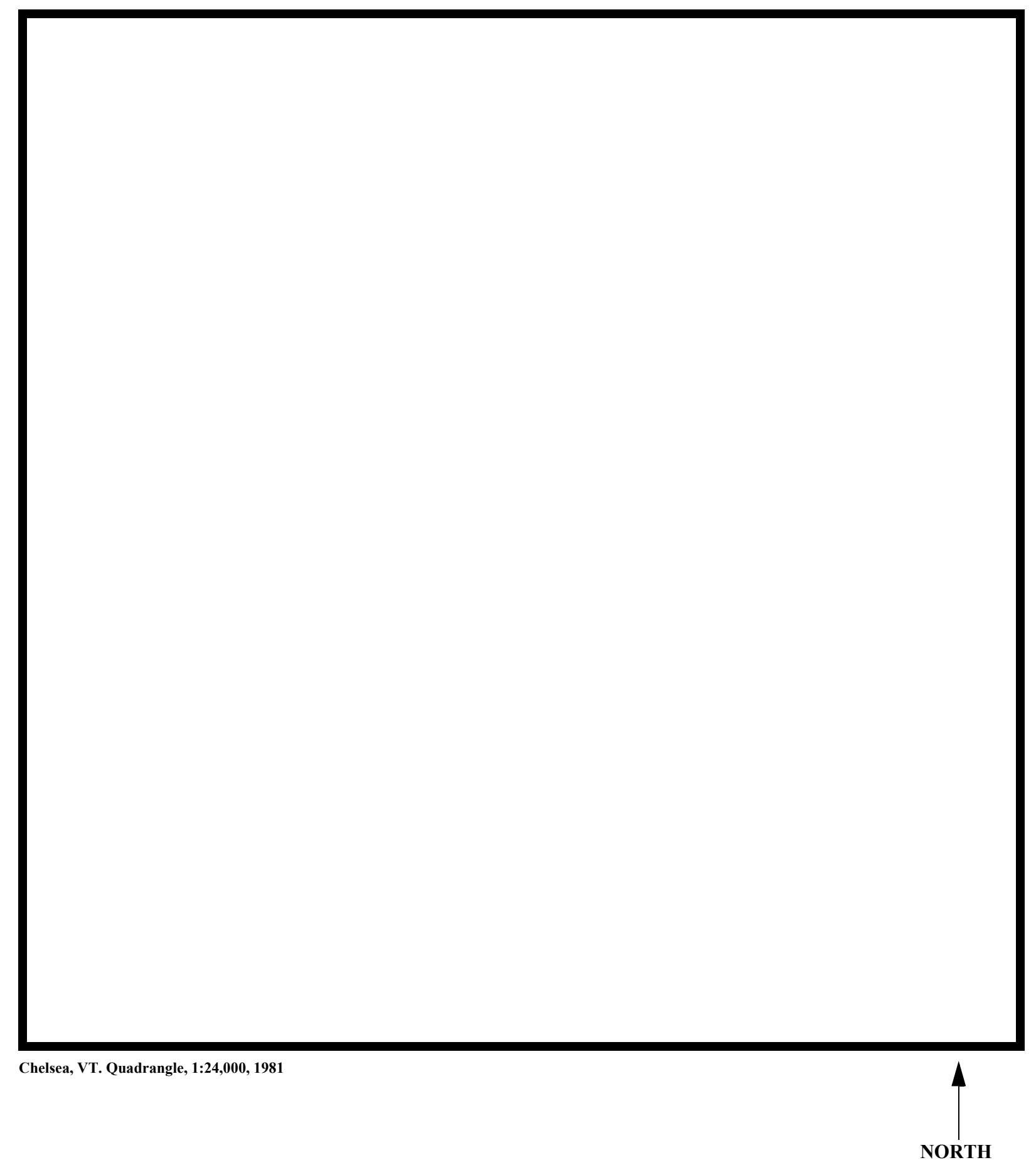

Figure 1. Location of study area on USGS 1:24,000 scale map. 
Figure 2. Location of study area on Vermont Agency of Transportation town highway map. 

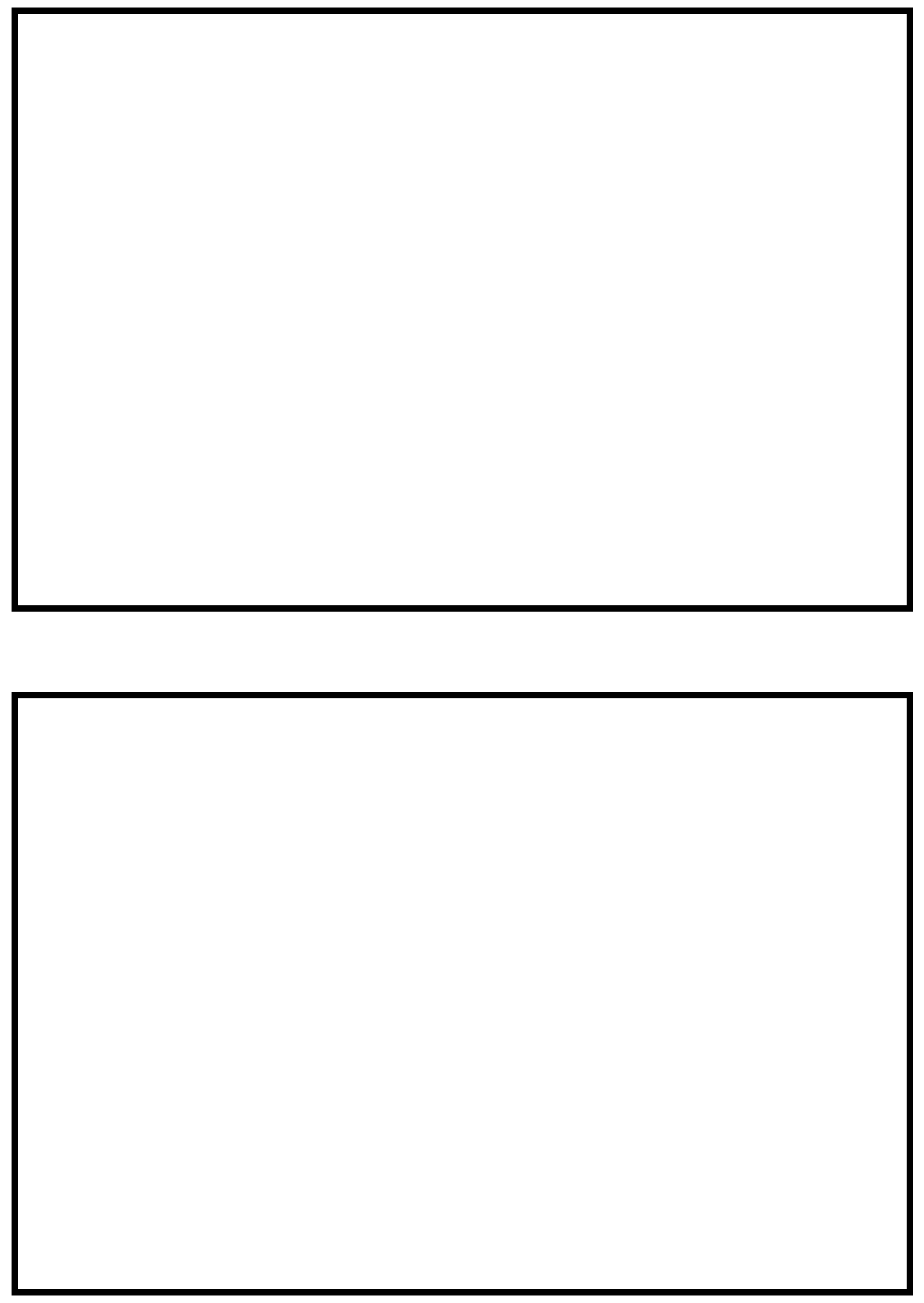

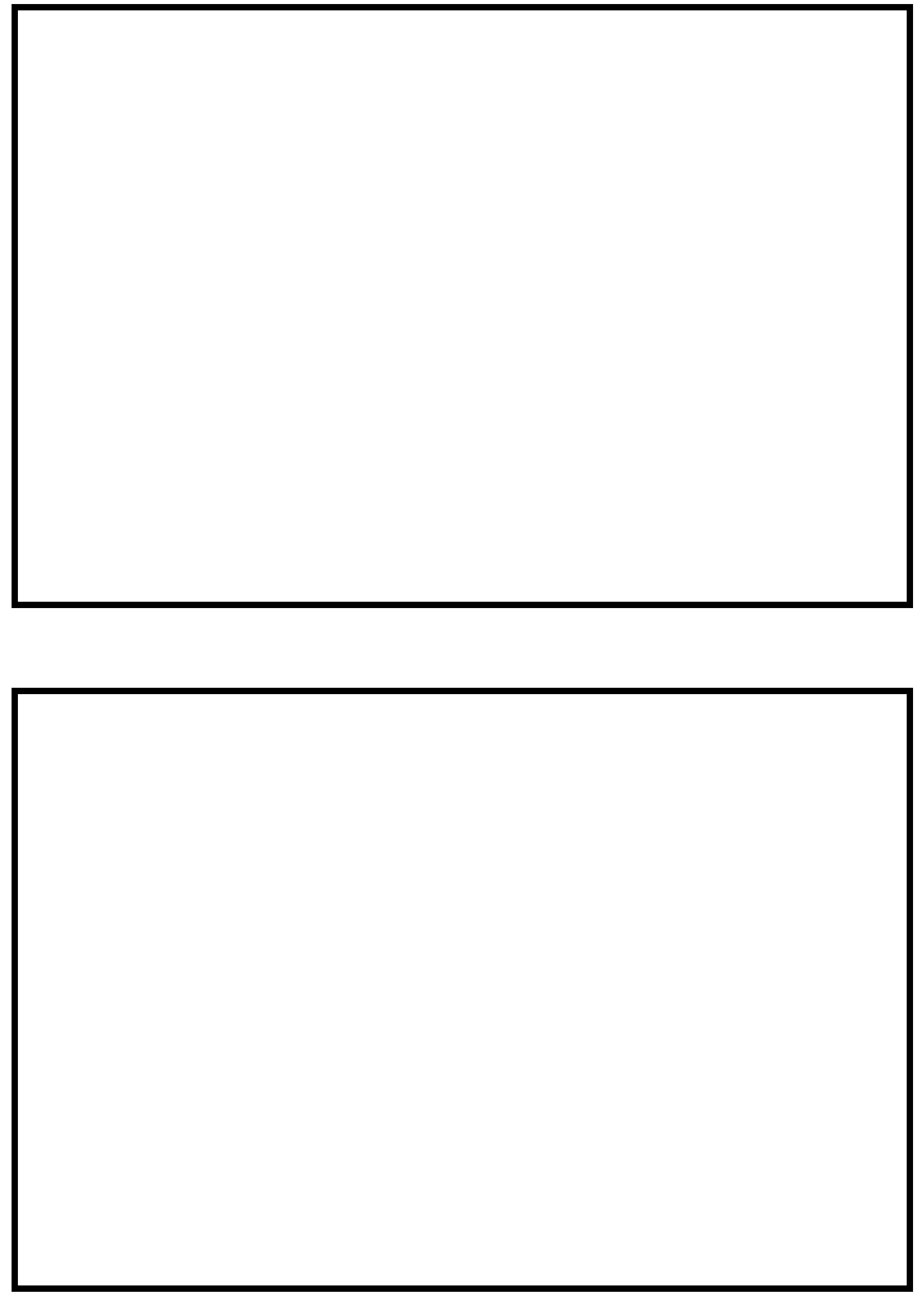


\section{LEVEL II SUMMARY}

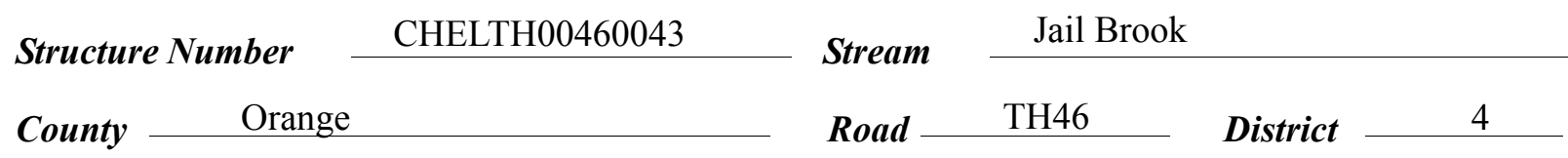

\section{Description of Bridge}

Bridge length $\frac{27}{2 t} \quad$ Bridge width $\stackrel{26.2}{f} \quad$ Max span length $\frac{23}{f t}$ Alignment of bridge to road (on curve or straight)

\begin{tabular}{|c|c|c|c|}
\hline \multirow{2}{*}{ Abutment type } & Vertical, concrete & \multirow{2}{*}{ Embankment type } & None \\
\hline & No & & $11 / 18 / 94$ \\
\hline
\end{tabular}

Abutments and wingwalls are concrete. The left abutment footing is exposed $1.0 \mathrm{ft}$.

$\overline{\mathrm{N}}$

$--$

\section{$\mathrm{N}$}

Is bridge skewed to flood flow according to 'survey?

Angle

$11 / 18 / 94$

$<10 \%$

Debris accumulation on bridge at time of Level I or Level II site visit:

\begin{tabular}{|c|c|c|c|}
\hline & $\begin{array}{c}\text { Date of incnortion } \\
<10 \%\end{array}$ & 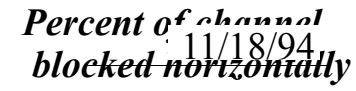 & $\begin{array}{l}\text { Percent o }<10 \% \text { el } \\
\text { blocked verticatty }\end{array}$ \\
\hline Level I & $<10 \%$ & Moderat & e. There \\
\hline $\begin{array}{l}\text { Level II } \\
\text { face. }\end{array}$ & \multicolumn{3}{|c|}{ is some debris caught on the channel bar at the downstream bridge } \\
\hline
\end{tabular}

November 18, 1994. Homes have been built directly on the edge of the channel.

Doscriho anv, fonturos noar ar at tho hridoo that mav, affort flow, (includo ahsorvation dato) 


\section{Description of the Geomorphic Setting}

General topography The channel is located within a narrow, flat valley with steep valley walls. Just downstream of the site, the stream enters the flood plain of the White River.

Geomorphic conditions at bridge site: downstream (DS), upstream (US)

Date of inspection $\quad 11 / 18 / 94$

DS left: $\quad$ Steep channel bank to a narrow terrace.

DS right: $\quad$ Steep channel bank to a narrow terrace.

US left: $\quad$ Steep channel bank to a narrow terrace.

US right: $\quad$ Steep channel bank to a narrow terrace.

\section{Description of the Channel}

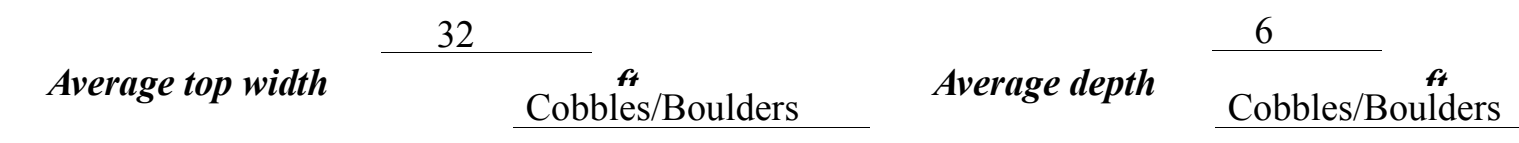

Predominant bed material

Bank material

Straight and stable

with alluvial and constructed channel boundaries and a narrow flood plain.

$11 / 18 / 94$

Vegetative co ${ }^{1}$ Lawns and homes with a few trees on the immediate channel bank.

DS left: $\quad$ Lawns and homes with a few trees on the immediate channel bank.

DS right: $\quad$ Lawns and homes with a few trees on the immediate channel bank.

US left: $\quad$ Lawns and homes with a few trees on the immediate channel bank.

US right: $\quad \underline{\mathrm{Y}}$

Do banks appear stable? -

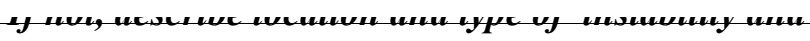

date of observatton.

The assessment of 11/

18/94 noted a channel bar at the downstream bridge face. There is some debris caught on the bar. Describe any obstructions in channel and date of observation. 


\section{Hydrology}

Drainage area $\stackrel{4.68}{\mathrm{mi}^{2}}$

Percentage of drainage area in physiographic provinces: (approximate)

Physiographic province/section New England/New England Upland
Percent of drainage area 100

Is drainage area considered rural or urban? Rural Describe any significant urbanization:

The site is located in the village of Chelsea. However, the drainage is considered rural.

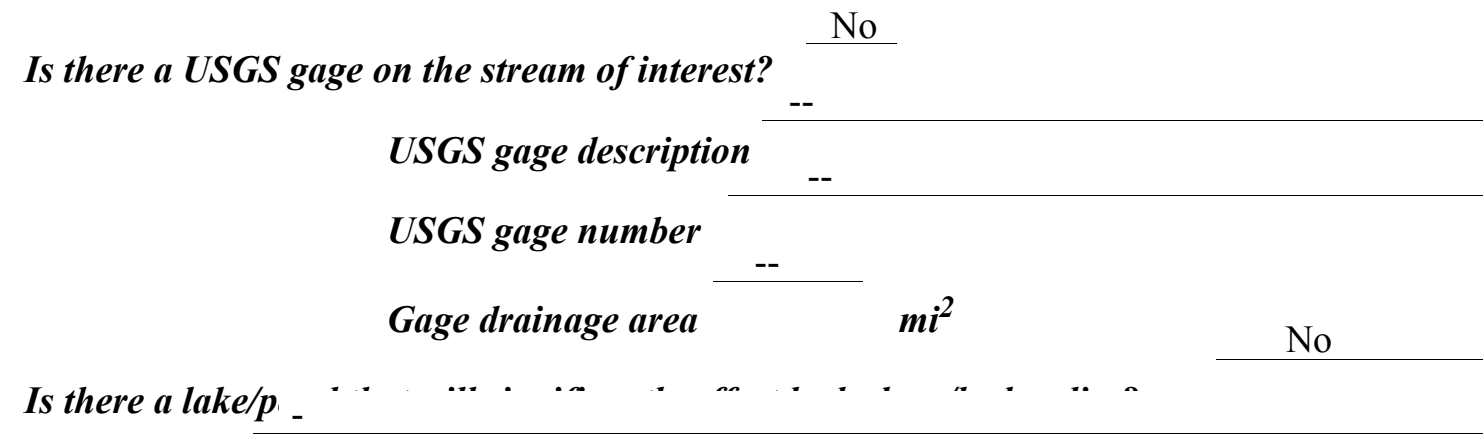

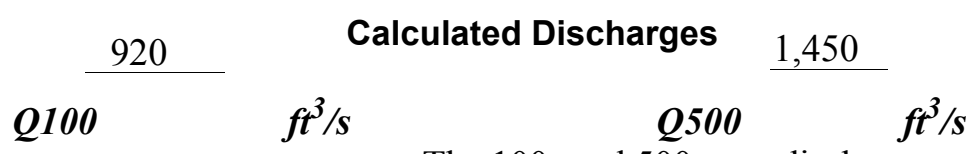

The 100- and 500-year discharges are taken directly

from the flood insurance study model (Dewberry and Davis, written communication, March 10, 1994). The selected discharges are within a range defined by flood frequency curves determined from several empirical methods (Benson, 1962; Johnson and Tasker, 1974; FHWA, 1983; Potter, 1957a\&b; Talbot, 1887). 


\section{Description of the Water-Surface Profile Model (WSPRO) Analysis}

Datum for WSPRO analysis (USGS survey, sea level, VTAOT plans)

USGS survey

Datum tie between USGS survey and VTAOT plans

None

Description of reference marks used to determine USGS datum. $\quad$ RM1 is a chiseled

square on the upstream left corner of the concrete bridge deck (elev. $99.50 \mathrm{ft}$, arbitrary survey

datum). RM2 is a chiseled square on downstream right corner of the concrete bridge deck (elev.

$99.65 \mathrm{ft}$, arbitrary survey datum).

\section{Cross-Sections Used in WSPRO Analysis}

\begin{tabular}{cccl}
\hline${ }^{1}$ Cross-section & $\begin{array}{c}\text { Section } \\
\text { Reference } \\
\text { Distance } \\
\text { (SRD) } \text { in feet }\end{array}$ & $\begin{array}{c}{ }^{2} \text { Cross-section } \\
\text { development }\end{array}$ & \multicolumn{1}{c}{ Comments } \\
\hline EXITX & -46 & 1 & Exit section \\
FULLV & 0 & 2 & $\begin{array}{l}\text { Downstream Full-valley } \\
\text { section (Templated from } \\
\text { EXITX) }\end{array}$ \\
BRIDG & 0 & 1 & Bridge section \\
RDWAY & 14 & 1 & Road Grade section \\
APPRO & 54 & 1 & Approach section \\
\hline
\end{tabular}

${ }^{1}$ For location of cross-sections see plan-view sketch included with Level I field form, Appendix E. For more detail on how cross-sections were developed see WSPRO input file. 


\section{Data and Assumptions Used in WSPRO Model}

Hydraulic analyses of the reach were done by use of the Federal Highway Administration's WSPRO step-backwater computer program (Shearman and others, 1986, and Shearman, 1990). The analyses reported herein reflect conditions existing at the site at the time of the study. Furthermore, in the development of the model it was necessary to assume no accumulation of debris or ice at the site. Results of the hydraulic model are presented in the Bridge Hydraulic Summary, Appendix B, and figure 7.

Channel roughness factors (Manning's " $n$ ") used in the hydraulic model were estimated using field inspections at each cross section following the general guidelines described by Arcement and Schneider (1989). Final adjustments to the values were made during the modelling of the reach. Channel " $n$ " values for the reach ranged from 0.050 to 0.065 , and overbank " $n$ " values ranged from 0.045 to 0.075 .

Normal depth at the exit section (EXITX) was assumed as the starting water surface. This depth was computed by use of the slope-conveyance method outlined in the user's manual for WSPRO (Shearman, 1990). The slope used was $0.022 \mathrm{ft} / \mathrm{ft}$. This was the 100 -year watersurface profile slope immediately downstream of the bridge in the Flood Insurance Study for the Town of Chelsea (Federal Emergency Management Agency, 1980).

The approach section (APPRO) was surveyed one bridge length upstream of the upstream face as recommended by Shearman and others (1986). This location also provides a consistent method for determining scour variables.

For the 100- and 500-year discharges, WSPRO assumes critical depth at the bridge section. Supercritical models were developed for these discharges. After analyzing both the supercritical and subcritical profiles for each discharge, it can be determined that the water surface profile does pass through critical depth within the bridge opening. Thus, the assumptions of critical depth at the bridge are satisfactory solutions. 


\section{Bridge Hydraulics Summary}

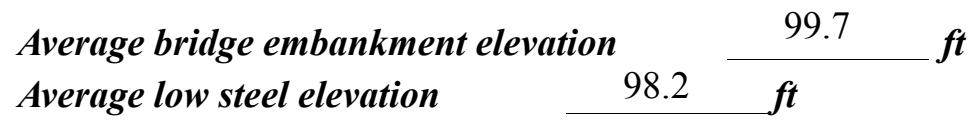

100-year discharge $\quad 920 \quad \mathrm{ft}^{3} / \mathrm{s}$

Water-surface elevation in bridge opening

$94.4 f t$

Road overtopping? ___ N Discharge over road ___ $\mathrm{ft}^{3} / \mathrm{s}$

Area of flow in bridge opening $\quad 83.2 \quad \mathrm{ft}^{2}$

Average velocity in bridge opening $11.1 \mathrm{ft} / \mathrm{s}$

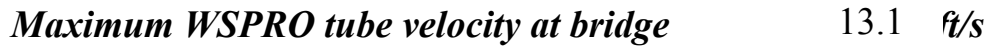

Water-surface elevation at Approach section with bridge $\quad 97.0$

Water-surface elevation at Approach section without bridge $\quad \cdot 95.9$

Amount of backwater caused by bridge

1.1 it

500-year discharge $\quad 1,450 \quad \mathrm{ft}^{3} / \mathrm{s}$

Water-surface elevation in bridge opening

$95.8 \mathrm{ft}$

Road overtopping? ___ N Discharge over road

$--,{ }^{3}, / s$

Area of flow in bridge opening

$113 \quad \mathrm{ft}^{2}$

Average velocity in bridge opening $12.8 \mathrm{ft} / \mathrm{s}$

Maximum WSPRO tube velocity at bridge 15.6 _s

Water-surface elevation at Approach section with bridge 98.8

Water-surface elevation at Approach section without bridge $\quad 97.3$

Amount of backwater caused by bridge $\quad 1.5, t$

Incipient overtopping discharge ___ -- $f^{3} / \mathrm{s}$

Water-surface elevation in bridge opening $\quad--\quad t$

Area of flow in bridge opening _ -- $\mathrm{ft}^{2}$

Average velocity in bridge opening __- $\quad \mathrm{ft} / \mathrm{s}$

Maximum WSPRO tube velocity at bridge __ -- $\mathrm{ft} / \mathrm{s}$

Water-surface elevation at Approach section with bridge

Water-surface elevation at Approach section without bridge

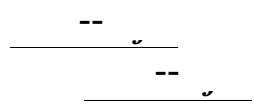

Amount of backwater caused by bridge _ 


\section{Scour Analysis Summary}

\section{Special Conditions or Assumptions Made in Scour Analysis}

Scour depths were computed using the general guidelines described in Hydraulic Engineering Circular 18 (Richardson and others, 1995). Scour depths were calculated assuming an infinite depth of erosive material and a homogeneous particle-size distribution. The results of the scour analysis are presented in tables 1 and 2 and a graph of the scour depths is presented in figure 8.

Contraction scour was computed by use of Laursen's live-bed contraction scour equation (Richardson and others, 1995, p. 30, equation 17). Contraction scour results are provided in Appendix F and shown in Figure 8.

Abutment scour was computed by use of the Froehlich equation (Richardson and others, 1995, p. 48, equation 28). Variables for the Froehlich equation include the Froude number of the flow approaching the embankments, the length of the embankment blocking flow, and the depth of flow approaching the embankment less any roadway overtopping. 


\section{Scour Results}

100-yr discharge 500-yr discharge

Incipient

Contraction scour:

(Scour depths in feet)

Main channel

\section{Live-bed scour \\ Clear-water scour \\ Depth to armoring}

Left overbank

Right overbank

Local scour:

Abutment scour

Left abutment

5.0

6.5

4.7-

$6.2-$

Right abutment

Pier scour

Pier 1

Pier 2

Pier 3

Abutments:

Left abutment

Right abutment

Piers:

Pier 1

Pier 2

overtopping discharge 


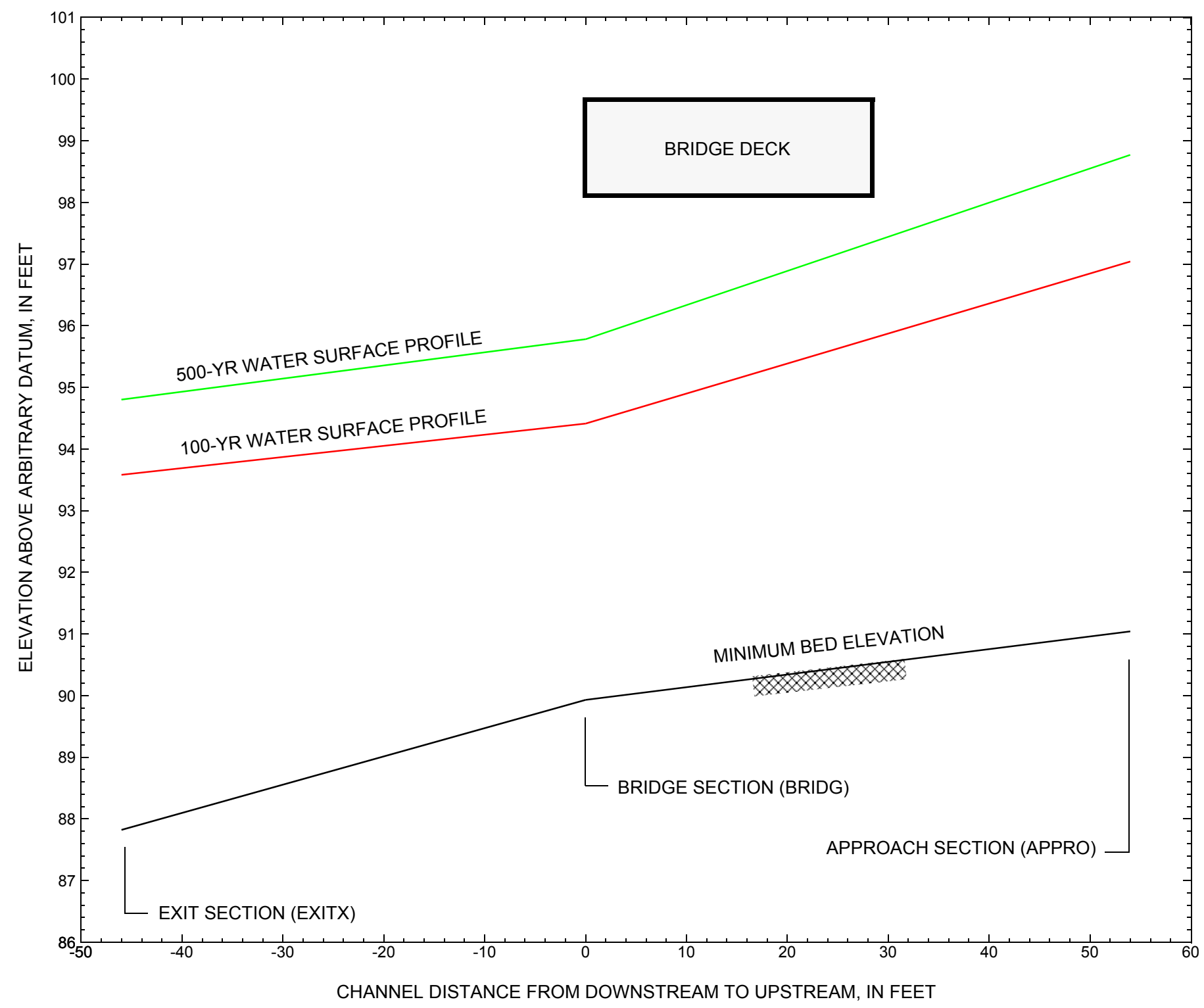

Figure 7. Water-surface profiles for the 100- and 500-yr discharges at structure CHELTH00460043 on Town Highway 46, crossing Jail Brook, Chelsea, Vermont. 


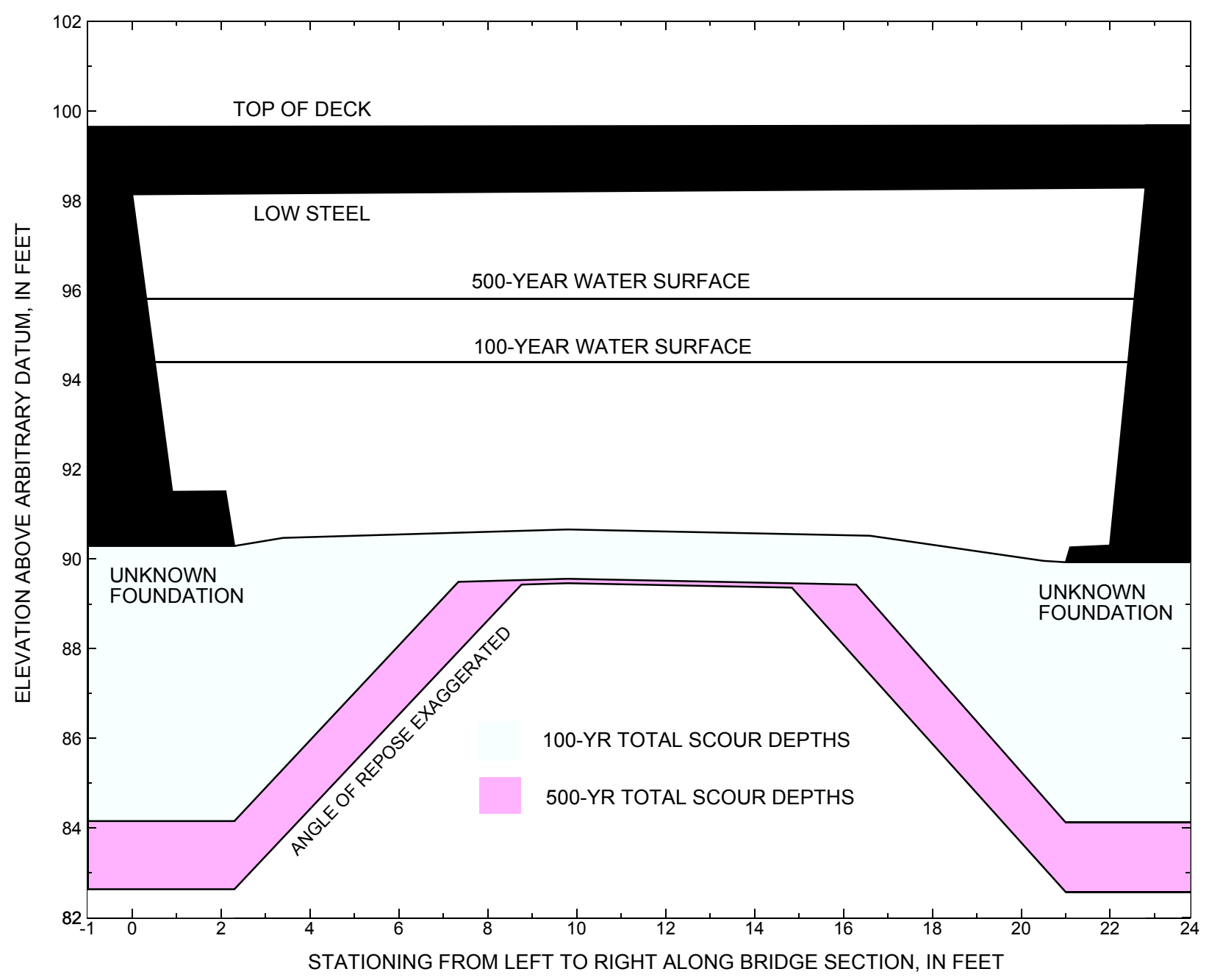

Figure 8. Scour elevations for the 100-yr and 500-yr discharges at structure CHELTH00460043 on Town Highway 46, crossing Jail Brook, Chelsea, Vermont. 


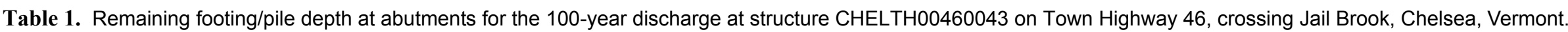
[VTAOT, Vermont Agency of Transportation; --,no data]

\begin{tabular}{|c|c|c|c|c|c|c|c|c|c|c|c|}
\hline Description & Station $^{1}$ & $\begin{array}{l}\text { VTAOT } \\
\text { minimum } \\
\text { low-chord } \\
\text { elevation } \\
\text { (feet) }\end{array}$ & $\begin{array}{l}\text { Surveyed } \\
\text { minimum } \\
\text { low-chord } \\
\text { elevation } \\
\text { (feet) }\end{array}$ & $\begin{array}{c}\text { Bottom of } \\
\text { footing } \\
\text { elevation } \\
\text { (feet) }\end{array}$ & $\begin{array}{l}\text { Channel } \\
\text { elevation at } \\
\text { abutment/ } \\
\text { pier }^{2} \\
\text { (feet) }\end{array}$ & $\begin{array}{l}\text { Contraction } \\
\text { scour depth } \\
\text { (feet) }\end{array}$ & $\begin{array}{l}\text { Abutment } \\
\text { scour } \\
\text { depth } \\
\text { (feet) }\end{array}$ & $\begin{array}{l}\text { Pier } \\
\text { scour } \\
\text { depth } \\
\text { (feet) }\end{array}$ & $\begin{array}{l}\text { Depth of } \\
\text { total scour } \\
\text { (feet) }\end{array}$ & $\begin{array}{c}\text { Elevation of } \\
\text { scour }^{2} \\
\text { (feet) }\end{array}$ & $\begin{array}{c}\text { Remaining } \\
\text { footing/pile } \\
\text { depth } \\
\text { (feet) }\end{array}$ \\
\hline \multicolumn{12}{|c|}{100 -yr. discharge is 920 cubic-feet per second } \\
\hline Left abutment & 0.0 & -- & 98.1 & -- & 90.3 & 1.1 & 5.0 & -- & 6.1 & 84.2 & -- \\
\hline Right abutment & 22.8 & -- & 98.3 & -- & 89.9 & 1.1 & 4.7 & -- & 5.8 & 84.1 & -- \\
\hline
\end{tabular}

1.Measured along the face of the most constricting side of the bridge.

2.Arbitrary datum for this study.

Table 2. Remaining footing/pile depth at abutments for the 500-year discharge at structure CHELTH00460043 on Town Highway 46, crossing Jail Brook, Chelsea, Vermont. [VTAOT, Vermont Agency of Transportation; --, no data]

\begin{tabular}{|c|c|c|c|c|c|c|c|c|c|c|c|}
\hline Description & Station $^{1}$ & $\begin{array}{l}\text { VTAOT } \\
\text { minimum } \\
\text { low-chord } \\
\text { elevation } \\
\text { (feet) }\end{array}$ & $\begin{array}{c}\text { Surveyed } \\
\text { minimum } \\
\text { low-chord } \\
\text { elevation } \\
\text { (feet) }\end{array}$ & $\begin{array}{c}\text { Bottom of } \\
\text { footing } \\
\text { elevation } \\
\text { (feet) }\end{array}$ & $\begin{array}{c}\text { Channel } \\
\text { elevation at } \\
\text { abutment/ } \\
\text { pier }^{2} \\
\text { (feet) }\end{array}$ & $\begin{array}{l}\text { Contraction } \\
\text { scour depth } \\
\text { (feet) }\end{array}$ & $\begin{array}{l}\text { Abutment } \\
\text { scour } \\
\text { depth } \\
\text { (feet) }\end{array}$ & $\begin{array}{l}\text { Pier } \\
\text { scour } \\
\text { depth } \\
\text { (feet) }\end{array}$ & $\begin{array}{l}\text { Depth of } \\
\text { total scour } \\
\text { (feet) }\end{array}$ & $\begin{array}{c}\text { Elevation of } \\
\text { scour }^{2} \\
\text { (feet) }\end{array}$ & $\begin{array}{c}\text { Remaining } \\
\text { footing/pile } \\
\text { depth } \\
\text { (feet) }\end{array}$ \\
\hline \multicolumn{12}{|c|}{500 -yr. discharge is 1,450 cubic-feet per second } \\
\hline Left abutment & 0.0 & -- & 98.1 & -- & 90.3 & 1.2 & 6.5 & -- & 7.7 & 82.6 & -- \\
\hline Right abutment & 22.8 & -- & 98.3 & -- & 89.9 & 1.2 & 6.2 & -- & 7.4 & 82.5 & -- \\
\hline
\end{tabular}

1.Measured along the face of the most constricting side of the bridge.

2.Arbitrary datum for this study. 


\section{SELECTED REFERENCES}

Arcement, G.J., Jr., and Schneider, V.R., 1989, Guide for selecting Manning's roughness coefficients for natural channels and flood plains:

U.S. Geological Survey Water-Supply Paper 2339, 38 p.

Barnes, H.H., Jr., 1967, Roughness characteristics of natural channels: U.S. Geological Survey Water-Supply Paper 1849,213 p.

Benson, M. A., 1962, Factors Influencing the Occurrence of Floods in a Humid Region of Diverse Terrain: U.S. Geological Survey WaterSupply Paper 1580-B, 64 p.

Brown, S.A. and Clyde, E.S., 1989, Design of riprap revetment: Federal Highway Administration Hydraulic Engineering Circular No. 11, Publication FHWA-IP-89-016, 156 p.

Federal Highway Administration, 1983, Runoff estimates for small watersheds and development of sound design: Federal Highway Administration Report FHWA-RD-77-158.

Federal Highway Administration, 1993, Stream Stability and Scour at Highway Bridges: Participant Workbook: Federal Highway Administration Report FHWA-HI-91-011.

Federal Emergency Management Agency, 1980, Flood Insurance Study, Town of Chelsea, Orange County, Vermont: Washington, D.C., February 1980.

Froehlich, D.C., 1989, Local scour at bridge abutments in Ports, M.A., ed., Hydraulic Engineering--Proceedings of the 1989 National Conference on Hydraulic Engineering: New York, American Society of Civil Engineers, p. 13-18.

Hayes, D.C.,1993, Site selection and collection of bridge-scour data in Delaware, Maryland, and Virginia: U.S. Geological Survey WaterResources Investigation Report 93-4017, 23 p.

Interagency Advisory Committee on Water Data, 1982, Guidelines for determining flood flow frequency: U.S. Geological Survey, Bulletin 17B of the Hydrology Subcommittee, 190 p.

Johnson, C.G. and Tasker, G.D.,1974, Progress report on flood magnitude and frequency of Vermont streams: U.S. Geological Survey OpenFile Report 74-130, 37 p.

Lagasse, P.F., Schall, J.D., Johnson, F., Richardson, E.V., Chang, F., 1995, Stream Stability at Highway Structures: Federal Highway Administration Hydraulic Engineering Circular No. 20, Publication FHWA-IP-90-014, 144 p.

Laursen, E.M., 1960, Scour at bridge crossings: Journal of the Hydraulics Division, American Society of Civil Engineers, v. 86, no. HY2, p. 39-53.

Potter, W. D., 1957a, Peak rates of runoff in the Adirondack, White Mountains, and Maine woods area, Bureau of Public Roads

Potter, W. D., 1957b, Peak rates of runoff in the New England Hill and Lowland area, Bureau of Public Roads

Richardson, E.V. and Davis, S.R., 1995, Evaluating scour at bridges: Federal Highway Administration Hydraulic Engineering Circular No. 18, Publication FHWA-IP-90-017, 204 p.

Richardson, E.V., Simons, D.B., and Julien, P.Y., 1990, Highways in the river environment: Federal Highway Administration Publication FHWA-HI-90-016.

Ritter, D.F., 1984, Process Geomorphology: W.C. Brown Co., Debuque, Iowa, 603 p.

Shearman, J.O., 1990, User's manual for WSPRO--a computer model for water surface profile computations: Federal Highway Administration Publication FHWA-IP-89-027, 187 p.

Shearman, J.O., Kirby, W.H., Schneider, V.R., and Flippo, H.N., 1986, Bridge waterways analysis model; research report: Federal Highway Administration Publication FHWA-RD-86-108, 112 p.

Talbot, A.N., 1887, The determination of water-way for bridges and culverts.

U.S. Department of Transportation, 1993, Stream stability and scour at highway bridges, Participant Workbook: Federal Highway Administration Publication FHWA HI-91-011.

U.S. Geological Survey, 1981, Chelsea, Vermont 7.5 Minute Series quadrangle map: U.S. Geological Survey Topographic Maps, Scale $1: 24,000$. 


\section{APPENDIX A: \\ WSPRO INPUT FILE}




\section{WSPRO INPUT FILE}

XS

GR

GR

GR

GR

GR

$\mathrm{N}$

SA

*

XS

$\mathrm{N}$

SA

*

BR

GR

GR

GR

GR

CD

$\mathrm{N}$

*

$\mathrm{XR}$

GR

GR

AS

GR

GR

GR

GR

$\mathrm{N}$

SA

HP 1 BRIDG 94.41 194.41

HP 2 BRIDG 94.41 * * 920

HP 1 APPRO 97.04197 .04

HP 2 APPRO 97.04 * * 920

*

HP 1 BRIDG 95.78195 .78

$\mathrm{HP} 2$ BRIDG 95.78 * 1450

$\mathrm{HP} 1 \mathrm{APPRO} 98.77198 .77$

HP 2 APPRO 98.77 * * 1450

*

EX

ER

$920 \quad 1450$

$0.022 \quad 0.022$

$\operatorname{EXITX}-46$

RDWAY $\quad 14 \quad 26$

$89.5,99.82$

APPRO $\quad 54$

$12.5,91.58$
U.S. Geological Survey WSPRO Input File chel043.wsp

Hydraulic analysis for structure CHELTH00460043 Date: 01-MAY-96

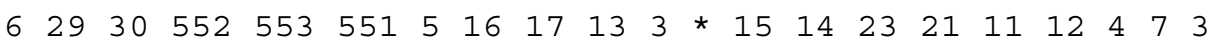

$5.1,89.32$

$8.9, \quad 87.82$

$24.3, \quad 90.81$

$\begin{array}{lccc}71.1, & 95.59 & 104.1, & 97.34 \\ 0.075 & 0.065 & 0.075\end{array}$

$-2.4 \quad 29.9$

FULLV $\quad 0 * * * 0.022$

$\begin{array}{lll}0.045 & 0.065 & 0.045 \\ & -2.4 & 29.9\end{array}$

\begin{tabular}{|c|c|c|c|c|c|c|c|}
\hline 0.0 , & 98.14 & 0.9 , & 91.50 & 2.1, & 91.51 & 2.3 & 90.29 \\
\hline 3.4, & 90.47 & 9.8, & 90.66 & 16.6 & 90.52 & 20.5 & 89.96 \\
\hline 21.0, & 89.93 & 21.1 & 90.26 & 22.0 & 90.30 & 22.0 & 90.65 \\
\hline 22.8, & 98.29 & 0.0 , & 98.14 & & & & \\
\hline
\end{tabular}

$\begin{array}{llllll}-60.0,105 & -60.0,99.84 & 0.0, & 99.65 & 23.3, & 99.68\end{array}$

$6.5,88.95$

$0.0, \quad 92.93$

$14.5,88.11$

$6.8,88.62$

$29.9, \quad 93.99$

$40.0, \quad 94.89$

$\begin{array}{llll}-54.7,100.76 & -6.6,99.54\end{array}$

$-2.9, \quad 97.82$

$-2.6, \quad 94.45$

$4.0,91.65$

$4.5, \quad 91.13$

$9.3,91.04$

$17.0, \quad 92.28$

$19.0, \quad 93.16$

$19.9,96.68$

$23.7,98.56 \quad 32.5,99.90$

$79.0,102.42$

0.045

23.7$$
\text { (1) }
$$ 


\section{APPENDIX B: \\ WSPRO OUTPUT FILE}


WSPRO OUTPUT FILE

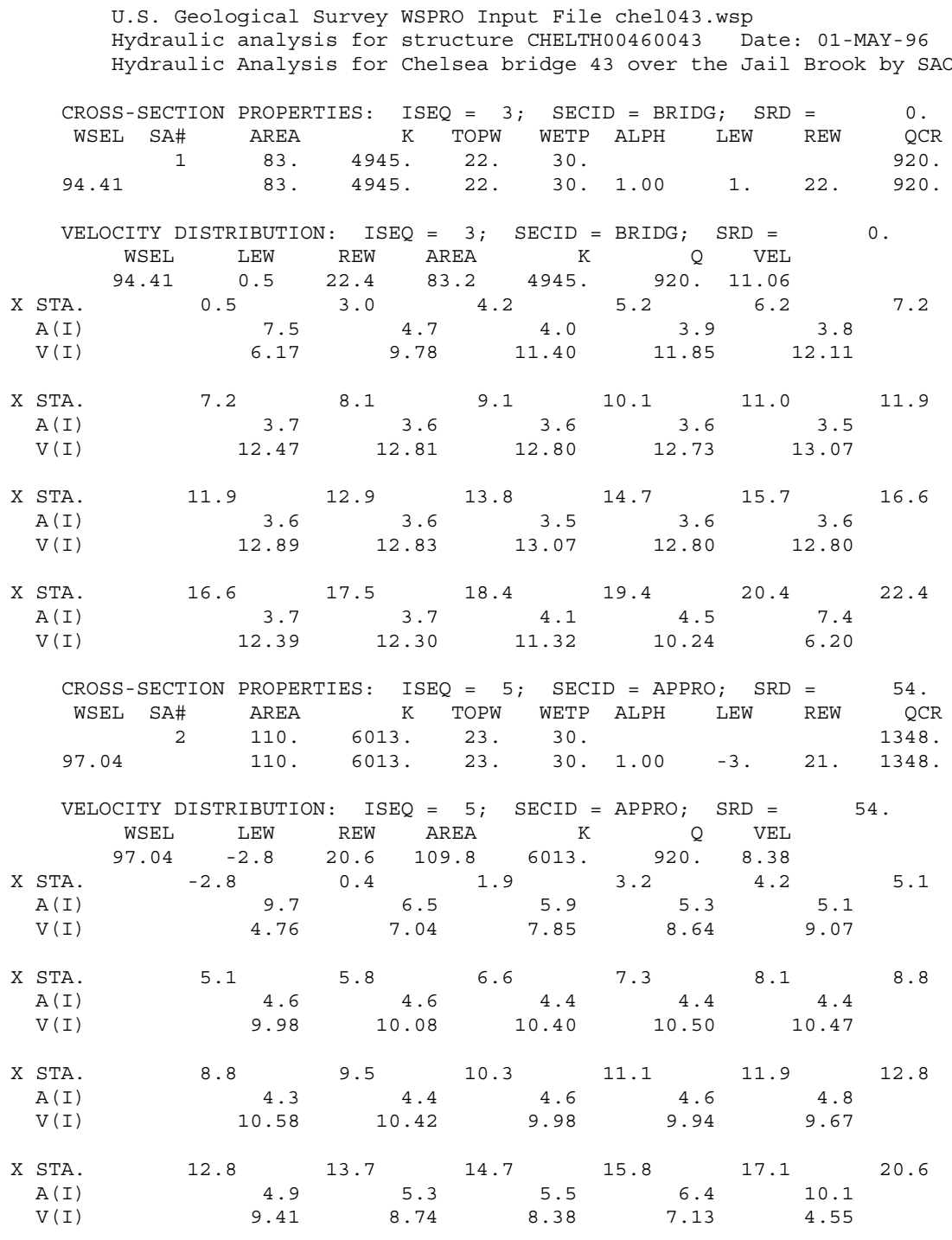


WSPRO OUTPUT FILE (continued)

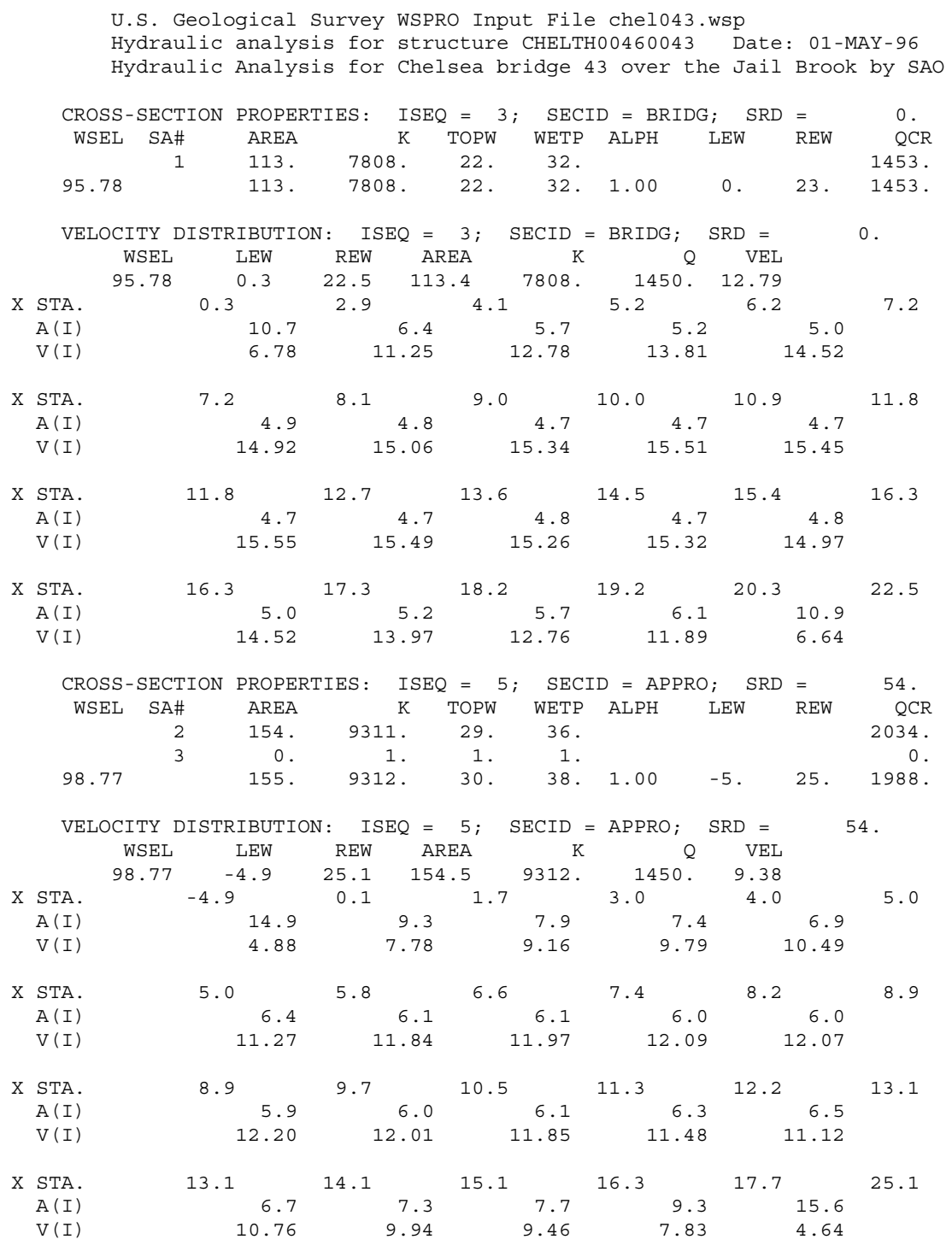


WSPRO OUTPUT FILE (continued)

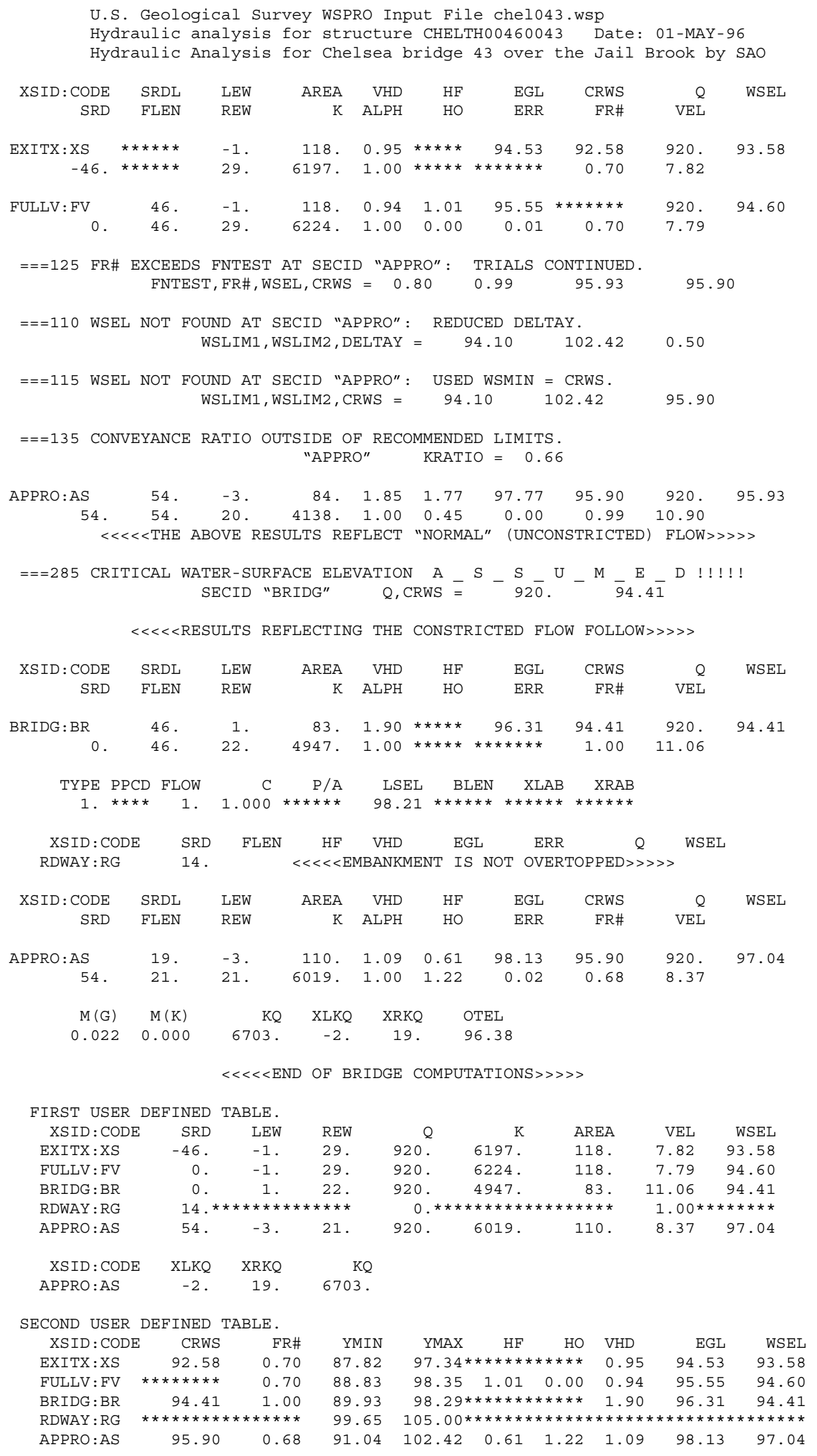


WSPRO OUTPUT FILE (continued)

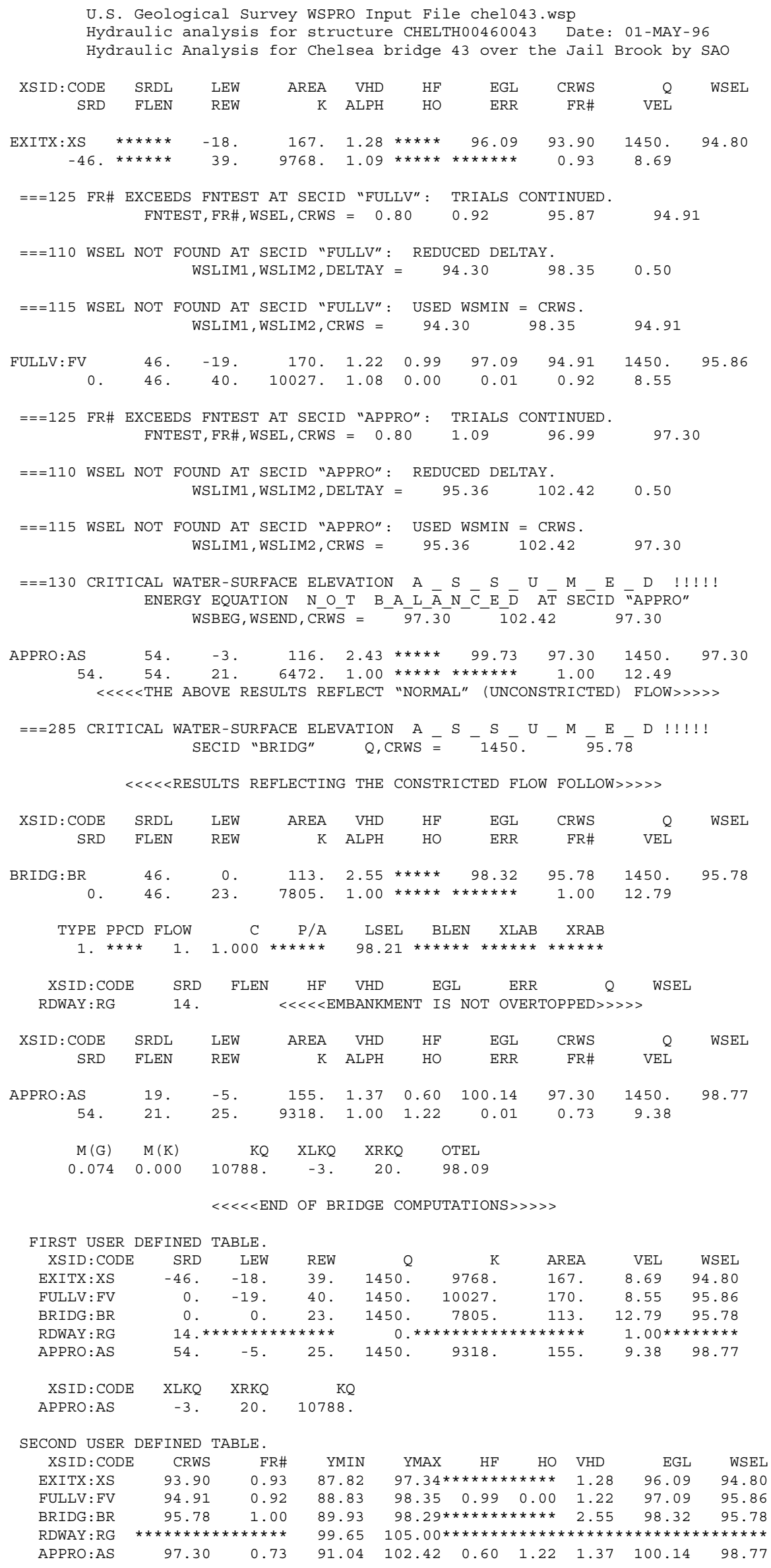




\section{APPENDIX C:}

\section{BED-MATERIAL PARTICLE-SIZE DISTRIBUTION}




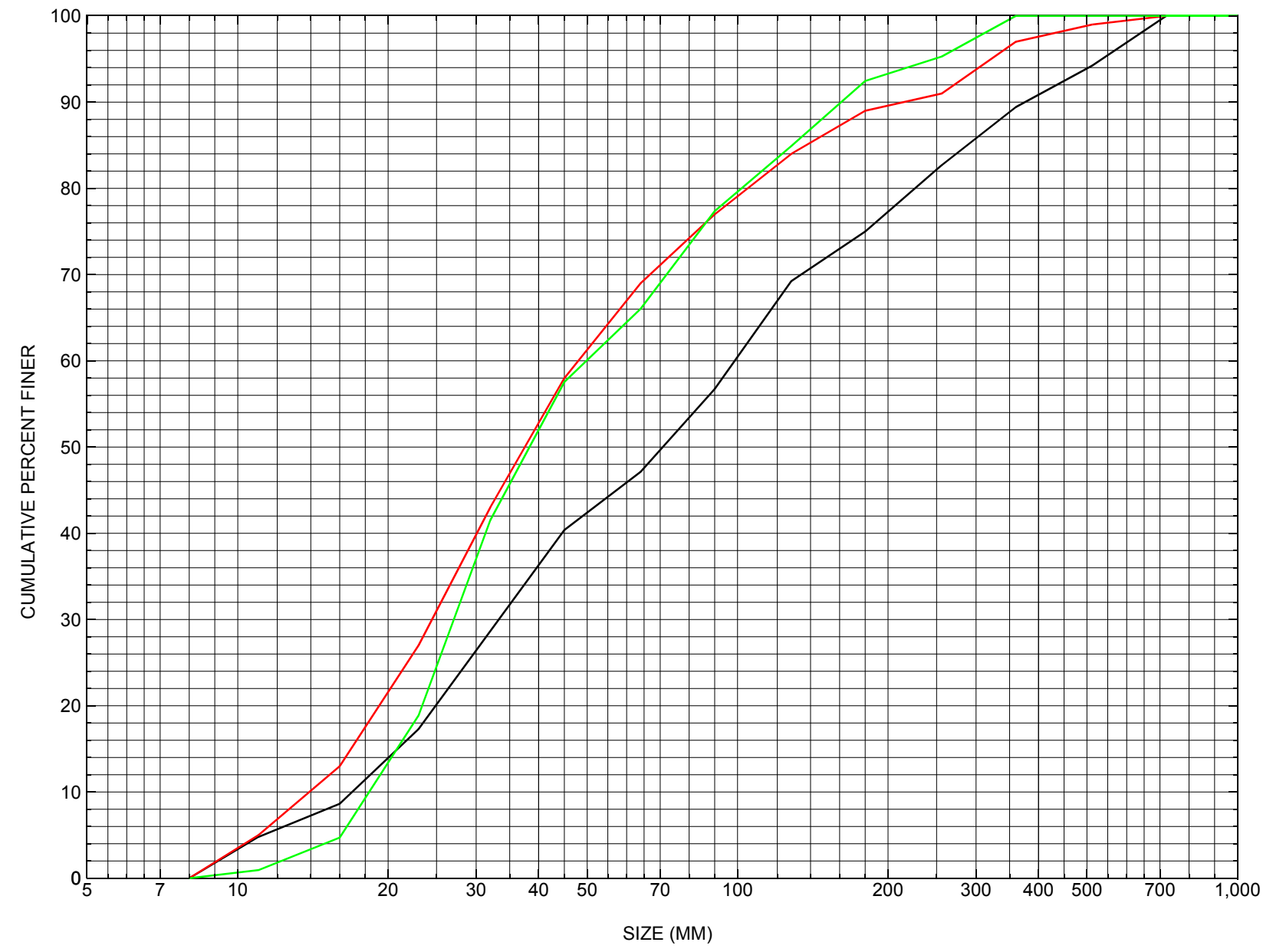

Appendix C. Bed material particle-size distribution for three pebble count transects in the channel approach of structure CHELTH00460043, in Chelsea, Vermont. 


\section{APPENDIX D: \\ HISTORICAL DATA FORM}




\section{Structure Number CHELTH00460043}

\section{General Location Descriptive}

Data collected by (First Initial, Full last name) $\underline{\text { M. IVANOFF }}$

Date $(M M / D D / Y Y) \_\mathbf{0 8} / \underline{\mathbf{2 5} /} \mathbf{9 4}$

Highway District Number (I - 2; nn) 04

Town (FIPS place code; I - 4; nnnnn) 13525

Waterway (I - 6) JAIL BRANCH

Route Number $\underline{\text { TH046 }}$

Topographic Map Chelsea

Latitude (I - 16; nnnn.n) $\mathbf{4 3 5 9 3}$
County (FIPS county code; I - 3; nnn)

Mile marker (I - 11; nnn.nnn) $\mathbf{0 0 0 0 0 0}$

Road Name (I - 7): -

Vicinity (I - 9) AT JCT TH 46 + VT 113

Hydrologic Unit Code: $\mathbf{0 1 0 8 0 1 0 5}$

Longitude (i - 17; nnnnn.n) $\mathbf{7 2 2 6 7}$

\section{Select Federal Inventory Codes}

FHWA Structure Number (I - 8) $\mathbf{1 0 0 9 0 4 0 0 4 3 0 9 0 4}$

Maintenance responsibility $(I-21 ; n n) \quad \mathbf{0 3} \quad$ Maximum span length $(I-48 ; n n n n) \underline{\mathbf{0 0 2 3}}$

Year built (I - 27; YYYY) 1964

Structure length (I - 49; nnnnnn) $\underline{\mathbf{0 0 0 0 2 7}}$

Average daily traffic, ADT (I - 29; nnnnnn) 000050

Deck Width (I - 52; nn.n) $\mathbf{2 6 2}$

Year of ADT (I - 30; YY) $\mathbf{9 1}$

Channel \& Protection $(I-61 ; n)$

Opening skew to Roadway $(I-34 ; n n) \quad \mathbf{0 0}$

Waterway adequacy $(I-71 ; n) \underline{7}$

Operational status $(I-41 ; X) \quad \mathbf{A}$

Underwater Inspection Frequency $(I-92 B ; X Y Y) \_\mathbf{N}$

Structure type (I - 43; nnn) 101

Year Reconstructed (I - 106) $\mathbf{0 0 0 0}$

Approach span structure type (I - 44; nnn) $\mathbf{0 0 0}$ Clear span (nnn.n ft) _

Number of spans (I - 45; nnn) $\mathbf{0 0 1}$

Vertical clearance from streambed (nnn.n ft) $\underline{\mathbf{0 0 7 . 0}}$

Number of approach spans (I - 46; nnnn) $\mathbf{0 0 0 0}$ Waterway of full opening $\left(n n n . n \mathrm{ft}^{2}\right)$

Comments:

Structural report of $9 / 24 / 93$ indicates a concrete slab type bridge. The junction with 113 is just behind the right abutment. Both concrete abutment stems and wings are relatively clean with minor spalling at the upstream wing of the left abutment. The left abutment footing is exposed for the entire length. The streambed at the upstream end of the left abutment is 6 inches below the top of the footing and the downstream end is 18 inches below the top of footing. No apparent undermining. The stream has a straight alignment to the bridge. The stream bed consist of stone and boulder with a few gravel deposits. Minor embankment erosion and drift/vegetation near the downstream fascia. (continued on page 31) 


\section{Bridge Hydrologic Data}

Is there hydrologic data available? $\underline{\mathbf{N}}$ if No, type ctrl- $n$ h VTAOT Drainage area $\left(m i^{2}\right):$

Terrain character:

Stream character \& type: -

Streambed material: Stone boulders with a few gravel deposits

Discharge Data (cfs): $\quad \mathrm{Q}_{2.33}-$

$$
\mathrm{Q}_{50}
$$

$\mathrm{Q}_{25}$

$\mathrm{Q}_{500}$

Record flood date (MM /DD/YY): -

Water surface elevation (ft): -

Estimated Discharge (cfs): Velocity at $\mathrm{Q}$ $(\mathrm{ft} / \mathrm{s}):$

Ice conditions (Heavy, Moderate, Light) : -

Debris (Heavy, Moderate, Light):

The stage increases to maximum highwater elevation (Rapidly, Not rapidly):

The stream response is (Flashy, Not flashy):

Describe any significant site conditions upstream or downstream that may influence the stream's stage: -

Watershed storage area (in percent):

The watershed storage area is: - (1-mainly at the headwaters; 2- uniformly distributed; 3-immediatly upstream oi the site)

Water Surface Elevation Estimates for Existing Structure:

\begin{tabular}{|l|l|l|l|l|l|}
\hline Peak discharge frequency & $Q_{2.33}$ & $Q_{10}$ & $Q_{25}$ & $Q_{50}$ & $Q_{100}$ \\
Water surface elevation (ft) $)$ & - & - & - & - & - \\
Velocity $(\mathrm{ft} / \mathrm{sec})$ & - & - & - & - & - \\
\hline
\end{tabular}

Long term stream bed changes: -

Is the roadway overtopped below the $\mathrm{Q}_{100}$ ? (Yes, No, Unknown): $\mathbf{U} \quad$ Frequency: -

Relief Elevation $(f t)$ :

Discharge over roadway at $Q_{100}\left(f^{3} / \mathrm{sec}\right)$ :

Are there other structures nearby? (Yes, No, Unknown): Upstream distance (miles): Town: If No or Unknown, type ctrl-n os Highway No. : Structure No. : Year Built:

Clear span (ft): Clear Height (ft): Full Waterway $\left(f t^{2}\right)$ : 
Downstream distance (miles): Town: Year Built:

Highway No. : Structure No. : Structure Type:

Clear span (ft): Clear Height $(f t)$ : Full Waterway $\left(f^{2}\right)$ :

Comments:

Stone fill is natural stone and boulder. The bridge has a paved road approach with flat embankments.

\section{USGS Watershed Data}

Watershed Hydrographic Data

Drainage area $(D A)$

Watershed storage (ST)

Bridge site elevation

Main channel length 840 4.08 $10 \%$ channel length elevation $\mathbf{9 7 0}$

Main channel slope

(S) 222.67 $\mathrm{ft} / \mathrm{mi}$

Watershed Precipitation Data

Average site precipitation in Average headwater precipitation in

Maximum 2yr-24hr precipitation event $(124,2)$ in

Average seasonal snowfall (Sn) $\mathrm{ft}$ 


\section{Bridge Plan Data}

Are plans available? If no, type ctrl-n pl

Project Number --

Minimum channel bed elevation: --

Low superstructure elevation: USLAB -DSLAB --

Benchmark location description:

NO BENCHMARK INFORMATION

Reference Point (MSL, Arbitrary, Other):

Datum (NAD27, NAD83, Other):

Foundation Type: 4

If 1: Footing Thickness

If 2: Pile Type: (1-Wood; 2-Ste
elevation:
available?

(1-Spreadfooting; 2-Pile; 3- Gravity; 4-Unknown) USRAB -DSRAB --

If 3 : Footing bottom elevation:

Is boring information available? Footing bottom elevation:

Foundation Material Type: $\mathbf{3}$ (1-regolith, 2-bedrock, 3-unknown)

Briefly describe material at foundation bottom elevation or around piles:

NO FOUNDATION MATERIAL INFORMATION

Comments:

NO PLANS. 


\section{Cross-sectional Data}

Is cross-sectional data available? $\underline{\mathbf{Y}}$

If no, type ctrl-n xs

Source (FEMA, VTAOT, Other)? VTAOT

Comments:

Note: some cross sections are available for channel.

\begin{tabular}{|l|l|l|l|l|l|l|l|l|l|l|l|}
\hline Station & & & & & & & & & & & \\
\hline Feature & & & & & & & & & & & \\
\hline $\begin{array}{l}\text { Low cord } \\
\text { elevation }\end{array}$ & & & & & & & & & & & \\
\hline $\begin{array}{l}\text { Bed } \\
\text { elevation }\end{array}$ & & & & & & & & & & & \\
\hline $\begin{array}{l}\text { Low cord to } \\
\text { bed length }\end{array}$ & & & & & & & & & & & \\
\hline Station & & & & & & & & & & & \\
\hline Feature & & & & & & & & & & & \\
\hline $\begin{array}{l}\text { Low cord } \\
\text { elevation }\end{array}$ & & & & & & & & & & & \\
\hline $\begin{array}{l}\text { Bed } \\
\text { elevation }\end{array}$ & & & & & & & & & & & \\
\hline $\begin{array}{l}\text { Low cord to } \\
\text { bed length }\end{array}$ & & & & & & & & & & & \\
\hline
\end{tabular}

Source (FEMA, VTAOT, Other)? FEMA

Comments: Flood Insurance Study model.

\begin{tabular}{|l|l|l|l|l|l|l|l|l|l|l|l|}
\hline Station & $\mathbf{1 2 7}$ & $\mathbf{1 4 0}$ & $\mathbf{1 5 3}$ & & & & & & & & \\
\hline Feature & LAB & & RAB & & & & & & & & \\
\hline $\begin{array}{l}\text { Low cord } \\
\text { elevation }\end{array}$ & $\mathbf{8 3 4 . 1}$ & & $\mathbf{8 3 4 . 1}$ & & & & & & & & \\
\hline $\begin{array}{l}\text { Bed } \\
\text { elevation }\end{array}$ & $\mathbf{8 2 5 . 9}$ & $\mathbf{8 2 5 . 9}$ & $\mathbf{8 2 5 . 9}$ & & & & & & & & \\
\hline $\begin{array}{l}\text { Low cord to } \\
\text { bed length }\end{array}$ & $\mathbf{8 . 2}$ & & $\mathbf{8 . 2}$ & & & & & & & & \\
\hline Station & & & & & & & & & & & \\
\hline Feature & & & & & & & & & & & \\
\hline $\begin{array}{l}\text { Low cord } \\
\text { elevation }\end{array}$ & & & & & & & & & & & \\
\hline $\begin{array}{l}\text { Bed } \\
\text { elevation }\end{array}$ & & & & & & & & & & & \\
\hline $\begin{array}{l}\text { Low cord to } \\
\text { bed length }\end{array}$ & & & & & & & & & & & \\
\hline
\end{tabular}




\section{APPENDIX E: \\ LEVEL I DATA FORM}


U. S. Geological Survey

Bridge Field Data Collection and Processing Form

Qa/Qc Check by: MAI Date: 2/3/95

\section{Structure Number}

\section{A. General Location Descriptive}

1. Data collected by (First Initial, Full last name) D. SONG

2. Highway District Number 04

County ORANGE (017)

Waterway (I - 6) JAIL BRANCH

Route Number $\mathbf{\text { TH046 }}$

3. Descriptive comments:

At the junction of TH 46 and VT 113.
Date $(M M / D D / Y Y)$

$11 / 18 / 1994$
Mile marker $\underline{\mathbf{0}}$

Town CHELSEA (13525)

Road Name -

Hydrologic Unit Code: $\mathbf{0 1 0 8 0 1 0 5}$

\section{B. Bridge Deck Observations}

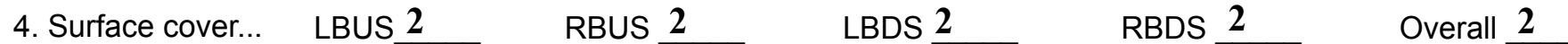

(2b us,ds,lb,rb: 1- Urban; 2- Suburban; 3- Row crops; 4- Pasture; 5- Shrub- and brushland; 6- Forest; 7- Wetland)

5. Ambient water surface...US $\underline{2}$ UB $\underline{2}$ DS $\underline{2}$ (1-pool; 2- riffle)

6. Bridge structure type 1 (1- single span; 2- multiple span; 3- single arch; 4- multiple arch; 5-cylindrical culvert; 6- box culvert; or 7- other)
7. Bridge length 27
(feet)
Span length $\underline{\mathbf{2 3}}$
(feet)
Bridge width 26.2 (feet)

\section{Road approach to bridge:}
8. LB 0
RB 0
( 0 even, 1- lower, 2- higher)
9. $\mathrm{LB}$
RB 1
(1- Paved, 2- Not paved)

10. Embankment slope (run / rise in feet / foot):

US left

US right

\begin{tabular}{|c|c|c|c|}
\hline \multicolumn{2}{|c|}{ Protection } & \multirow{2}{*}{ 13.Erosion } & 14.Severity \\
\hline 11.Type & 12.Cond. & $\mathbf{0}$ & - \\
\hline $\mathbf{2}$ & $\mathbf{1}$ & $\mathbf{0}$ & $\mathbf{1}$ \\
\hline $\mathbf{2}$ & $\mathbf{1}$ & $\mathbf{1}$ & $\mathbf{1}$ \\
$\mathbf{2}$ & $\mathbf{1}$ & $\mathbf{0}$ & $\mathbf{-}$ \\
\hline $\mathbf{2}$ & $\mathbf{1}$ & $\mathbf{2}$ & $\mathbf{1}$ \\
\hline
\end{tabular}

Bank protection types: 0- none; 1- < 12 inches;

2- < 36 inches; 3- < 48 inches;

4- < 60 inches; 5- wall / artificial levee

Bank protection conditions: 1- good; 2- slumped;

3- eroded; 4- failed

Erosion: 0 - none; 1- channel erosion; 2 -

road wash; 3- both; 4- other

Erosion Severity: 0 - none; 1- slight; 2- moderate; 3- severe

\section{Channel approach to bridge (BF):}

15. Angle of approach: $\mathbf{0}$

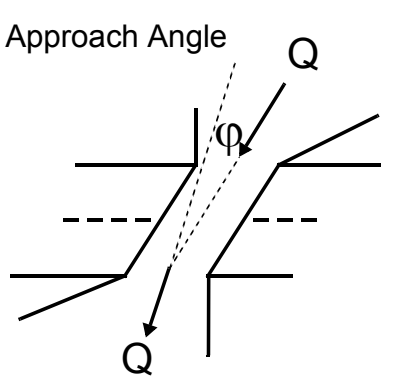

17. Channel impact zone 1:

Where? (LB, RB)

Range? feet

Channel impact zone 2:

Where? (LB, RB)

Range? feet (US, UB, DS) to feet

16. Bridge skew: $\mathbf{0}$ Bridge Skew Angle

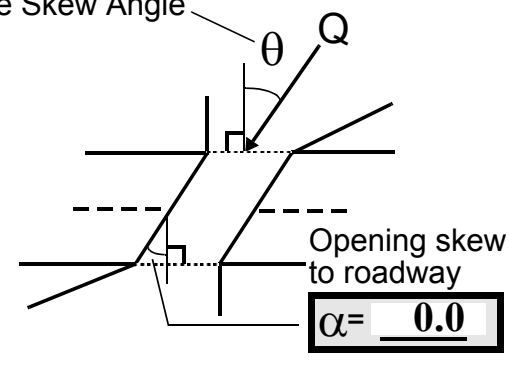

\section{Exist? $\underline{\mathbf{N}}(\mathrm{Y}$ or $N)$}

Severity

(US, UB, DS) to feet

Exist? $\mathbf{N}(Y$ or $N)$

Severity

Impact Severity: 0- none to very slight; 1- Slight; 2- Moderate; 3- Severe 
18. Bridge Type: 1a

1a- Vertical abutments with wingwalls

1 b- Vertical abutments without wingwalls

2- Vertical abutments and wingwalls, sloping embankment Wingwalls parallel to abut. face

3- Spill through abutments

4- Sloping embankment, vertical wingwalls and abutments

Wingwall angle less than $90^{\circ}$.

19. Bridge Deck Comments (surface cover variations, measured bridge and span lengths, bridge type variations, approach overflow width, etc.)

7. Measured bridge length: 28, clear span: 22.8 , and width: 26 feet.

11. Protection consists of boulders on the top of or at the ends of wingwalls.

Channel is straight throughout the reach; banks have been protected and built-up both upstream and downstream.

\section{Upstream Channel Assessment}

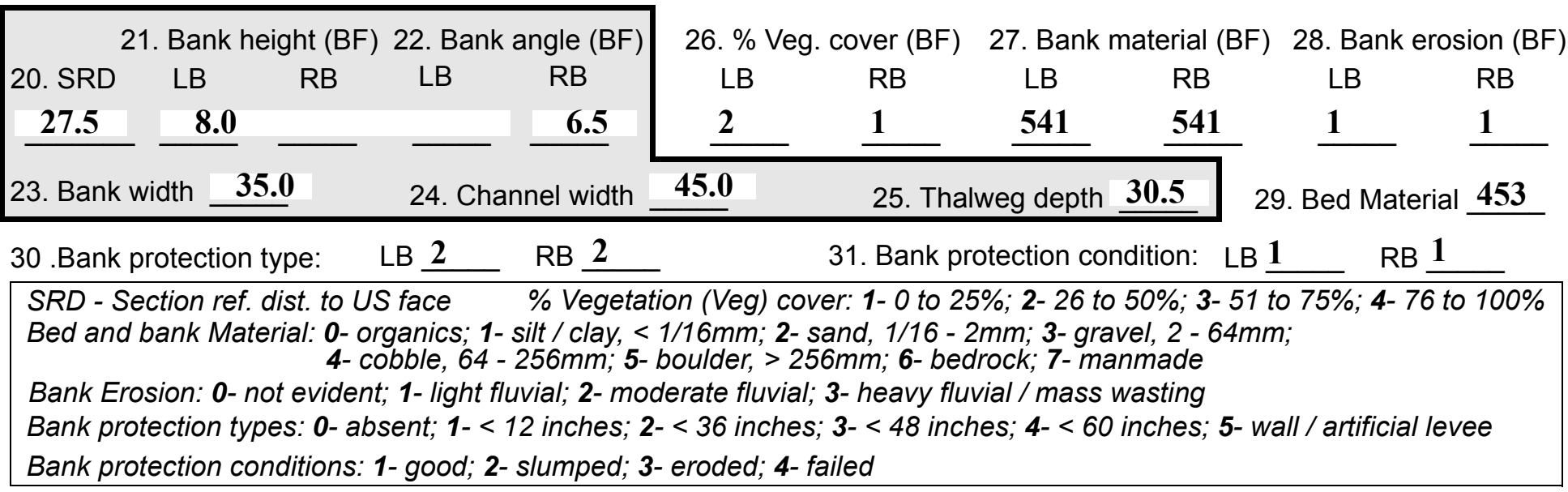

32. Comments (bank material variation, minor inflows, protection extent, etc.):

27. Banks are covered by stone fill (boulders). There is some localized slumping of the stone fill material.

30. Protection extends beyond $200 \mathrm{ft}$. upstream of the bridge.

Numerous drainage pipes (minor) into the channel. 
33.Point/Side bar present? $\mathbf{N}(Y$ or $N$. if $N$ type ctrl-n pb)34. Mid-bar distance: -

35. Mid-bar width:

36. Point bar extent: feet -

(US, UB) to feet -

(US, UB, DS) positioned -

$\%$ LB to $\% \mathrm{RB}$

37. Material:

38. Point or side bar comments (Circle Point or Side; Note additional bars, material variation, status, etc.):

NO POINT BARS

A small bar comprised of pebbles and gravel exists at low flow on the right bank.

39. Is a cut-bank present? $\mathbf{N}$ (Y or if $N$ type ctrl- $n c b)$

40. Where? (LB or $R B)$

41. Mid-bank distance: -

42. Cut bank extent: feet (US, UB) to feet (US, UB, DS)

43. Bank damage: (1- eroded and/or creep; 2- slip failure; 3- block failure)

44. Cut bank comments (eg. additional cut banks, protection condition, etc.):

NO CUT BANKS

45. Is channel scour present? $\mathbf{N}$ ( $Y$ or if $N$ type ctrl-n cs)

47. Scour dimensions: Length -

Width -

Depth : -

46. Mid-scour distance: -

48. Scour comments (eg. additional scour areas, local scouring process, etc.):

NO CHANNEL SCOUR

49. Are there major confluences? $\mathbf{N}$

51. Confluence 1: Distance Confluence 2: Distance -

52. Enters on -

Enters on -

4. Confluence comments (eg. confluence name):

NO MAJOR CONFLUENCES
50. How many? -

53. Type(1-perennial; 2- ephemeral)

Type (1- perennial; 2- ephemeral) ( $L B$ or $R B)$

\section{Under Bridge Channel Assessment}

55. Channel restraint (BF)? LB 2

\begin{tabular}{|ccccc}
\hline \multicolumn{2}{|c}{ 56. Height (BF) } & \multicolumn{3}{c}{57 Angle (BF) } \\
LB & RB & LB & RB \\
$\mathbf{1 3 . 0}$ & & $\mathbf{0 . 5}$ &
\end{tabular}

58. Bank width (BF) =

(1- natural bank; 2- abutment; 3- artificial levee)

Bed and bank Material: 0- organics; 1- silt / clay, < 1/16mm; 2- sand, 1/16 - 2mm; 3- gravel, 2 - 64mm; 4- cobble, 64 - 256mm; 5- boulder, > 256mm; 6- bedrock; 7- manmade

Bank Erosion: 0- not evident; 1- light fluvial; 2- moderate fluvial; 3- heavy fluvial / mass wasting

64. Comments (bank material variation, minor inflows, protection extent, etc.):

453

63. Bed material ranges from coarse sand to boulder. 
65. Debris and Ice Is there debris accumulation?

(Yor $N)$ 66. Where? $\underline{Y}$

(1- Upstream; 2- At bridge; 3- Both)

67. Debris Potential $\underline{2}$ ( 1- Low; 2- Moderate; 3- High)

68. Capture Efficiency 2 (1-Low; 2- Moderate; 3- High)

69. Is there evidence of ice build-up? 1 (Y or N)

Ice Blockage Potential $\mathbf{N}$

(1-Low; 2- Moderate; 3- High)

70. Debris and Ice Comments:

1

67. Some accumulation of debris on channel bar at downstream face of the bridge.

\begin{tabular}{|l|c|c|c|c|c|c|c|c|}
\hline Abutments & $\begin{array}{c}\text { 71. Attack } \\
\angle \text { (BF) }\end{array}$ & $\begin{array}{c}72 \text {. Slope } \angle \\
\text { (Qmax) }\end{array}$ & $\begin{array}{c}\text { 73. Toe } \\
\text { loc. (BF) }\end{array}$ & $\begin{array}{c}\text { 74. Scour } \\
\text { Condition }\end{array}$ & $\begin{array}{c}75 . \text { Scour } \\
\text { depth }\end{array}$ & $\begin{array}{c}\text { 76. Exposure } \\
\text { depth }\end{array}$ & 77. Material & 78. Length \\
\hline LABUT & & $\mathbf{0}$ & $\mathbf{9 0}$ & $\mathbf{2}$ & $\mathbf{2}$ & $\mathbf{0}$ & $\mathbf{1}$ & $\mathbf{9 0 . 0}$ \\
\hline RABUT & $\mathbf{1}$ & $\mathbf{0}$ & $\mathbf{9 0}$ & & & $\mathbf{2}$ & $\mathbf{2}$ & $\mathbf{2 3 . 0}$ \\
\hline
\end{tabular}

Pushed: $L B$ or RB

Toe Location (Loc.): 0- even, 1- set back, 2- protrudes

Scour cond.: 0- not evident; 1- evident (comment); 2- footing exposed; 3-undermined footing; 4- piling exposed; 5- settled; 6- failed

Materials: 1- Concrete; 2- Stone masonry or drywall; 3- steel or metal; 4- wood

79. Abutment comments (eg. undermined penetration, unusual scour processes, debris, etc.):

0

0

1

74. RABUT: Only the top of the footing is exposed, level with the channel; the footing is lower (about $1 \mathrm{ft}$.) than the left abutment footing.

80. Wingwalls:

Exist? Material? Scour Scour Exposure $\begin{aligned} & 81 . \\ & \text { Angle? Length? }\end{aligned}$ Condition? depth? depth?

USLWW:

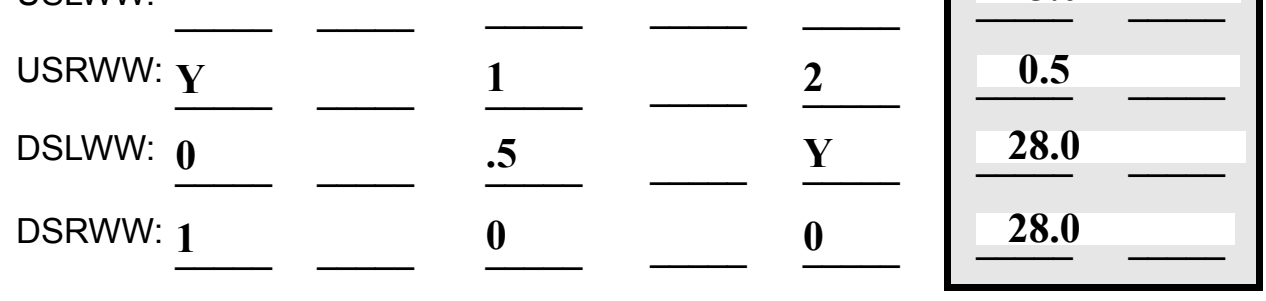

Wingwall materials: 1- Concrete; 2- Stone masonry or drywall; 3- steel or metal; 4- wood

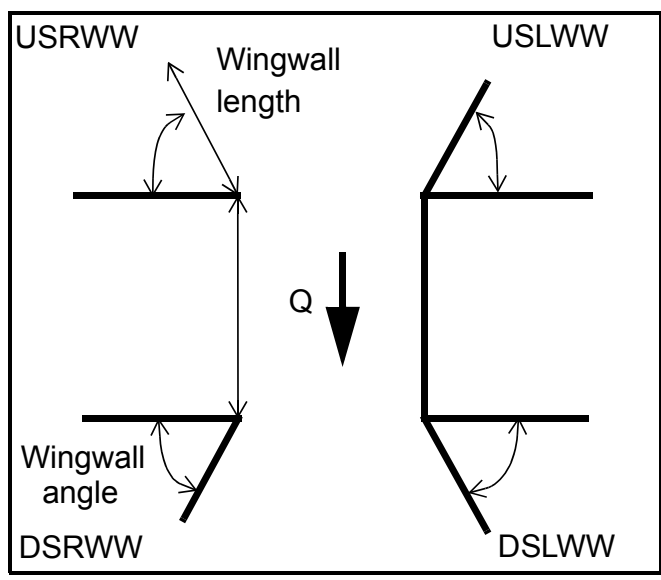

82. Bank / Bridge Protection:

\begin{tabular}{|l|l|l|l|l|l|l|c|c|}
\hline Location & USLWW & USRWW & LABUT & RABUT & LB & RB & DSLWW & DSRWW \\
\hline Type & $\mathbf{0}$ & $\mathbf{2}$ & $\mathbf{Y}$ & $\mathbf{0}$ & - & $\mathbf{1}$ & - & - \\
\hline Condition & $\mathbf{Y}$ & $\mathbf{0}$ & $\mathbf{1}$ & $\mathbf{0}$ & - & $\mathbf{2}$ & - & - \\
\hline Extent & $\mathbf{1}$ & $\mathbf{1}$ & $\mathbf{2}$ & $\mathbf{0}$ & $\mathbf{2}$ & $\mathbf{0}$ & $\mathbf{0}$ & - \\
\hline
\end{tabular}

Bank / Bridge protection types: 0- absent; 1- < 12 inches; 2- < 36 inches; 3- < 48 inches; 4- < 60 inches; 
83. Wingwall and protection comments (eg. undermined penetration, unusual scour processes, etc.):

-
-
-
-
-
2
1
2
1
1
2

\section{Piers:}

84. Are there piers? (Y or if $N$ type ctrl-n pr)

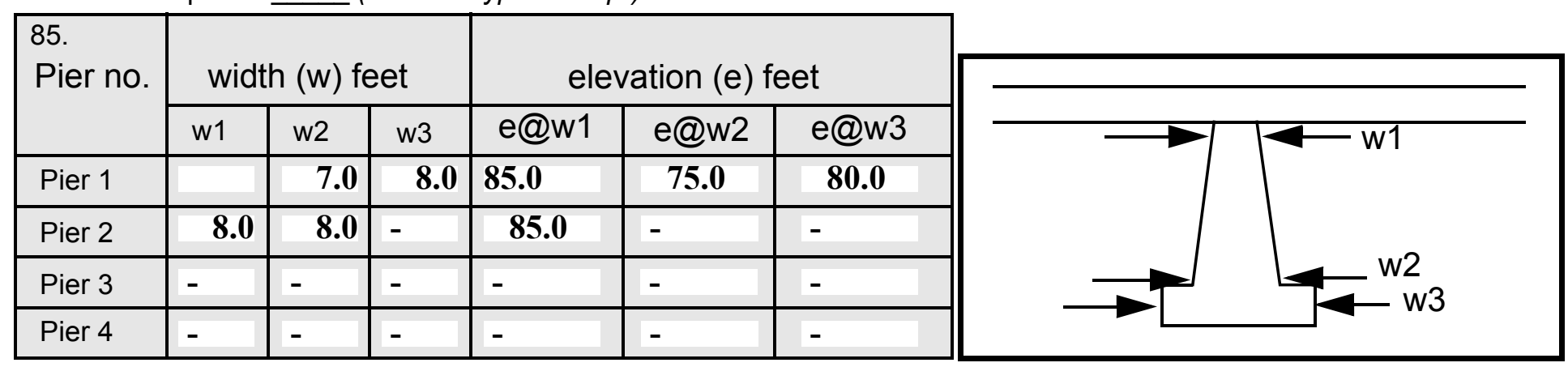

\begin{tabular}{|c|c|c|c|c|}
\hline Level 1 Pier Descr. & 1 & 2 & 3 & 4 \\
\hline 86. Location (BF) & & - & - & - \\
\hline 87. Type & & - & - & - \\
\hline 88. Material & & - & - & - \\
\hline 89. Shape & & - & - & - \\
\hline 90. Inclined? & & - & - & - \\
\hline 91. Attack $\angle(\mathrm{BF})$ & & - & - & - \\
\hline 92. Pushed & & - & - & - \\
\hline 93. Length (feet) & - & - & - & - \\
\hline 94. \# of piles & & - & - & - \\
\hline 95. Cross-members & & - & - & - \\
\hline 96. Scour Condition & & - & - & - \\
\hline 97. Scour depth & $\mathbf{N}$ & - & - & - \\
\hline 98. Exposure depth & - & - & - & - \\
\hline
\end{tabular}

LFP, LTB, LB, MCL, MCM, MCR, RB, RTB, RFP

1- Solid pier, 2- column, 3- bent

1-Wood; 2- concrete; 3- metal; 4- stone

1- Round; 2- Square; 3- Pointed

Y-yes; $N-$ no

$L B$ or $R B$

0- none; 1- laterals; 2- diagonals; 3- both

0- not evident; 1- evident (comment);

2- footing exposed; 3- piling exposed;

4- undermined footing; 5- settled; 6- failed 
99. Pier comments (eg. undermined penetration, protection and protection extent, unusual scour processes, etc.):

-
-
-
-
-
-
-
-
-
-

100.

\section{E. Downstream Channel Assessment}

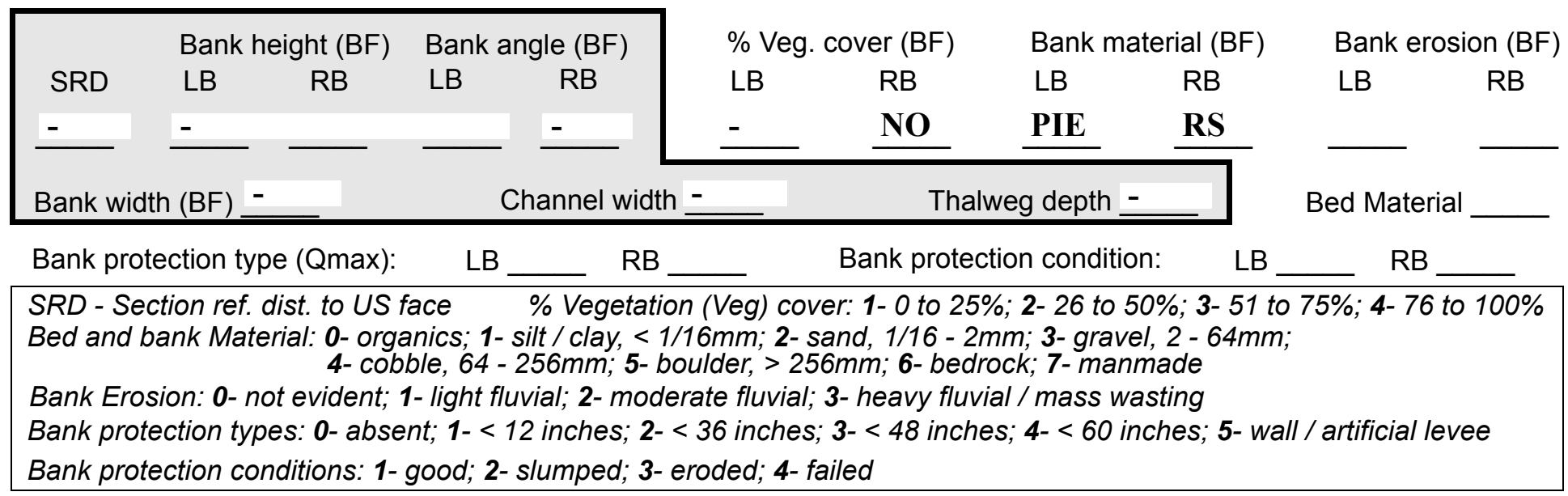

Comments (eg. bank material variation, minor inflows, protection extent, etc.):

1

1

541

541

0

1

453

2

2

2

1

Bed material ranges from course sand to boulder.

101. Is a drop structure present? Ba ( $Y$ or $N$, if $N$ type ctrl-n ds) 102. Distance: ___ feet

103. Drop: -_ feet 104. Structure material: $\mathbf{n k}$ (1- steel sheet pile; 2- wood pile; 3- concrete; 4- other) 105. Drop structure comments (eg. downstream scour depth):

protection extends beyond $200 \mathrm{ft}$. downstream of the bridge. The left bank protection has localized slumping about $30 \mathrm{ft}$. downstream, exposing the bank. 
106. Point/Side bar present? (Y or $N$. if $N$ type ctrl-n pb)Mid-bar distance:

Mid-bar width:

Point bar extent: feet

(US, UB, DS) to feet (US, UB, DS) positioned $\underline{\mathbf{N}}$ $\%$ LB to $\% R B$ Material: $\mathbf{N O}$

Point or side bar comments (Circle Point or Side; note additional bars, material variation, status, etc.):

\section{DROP STRUCTURE}

Is a cut-bank present? (Y or if $N$ type ctrl- $n$ cb) Where? (LB or $R B)$

Mid-bank distance: $\underline{\mathbf{Y}}$

Cut bank extent: $\mathbf{5}$ feet 18 (US, UB, DS) to $\underline{\mathbf{5}}$ feet $\underline{\mathbf{U B}}$ (US, UB, DS)

Bank damage: 15 (1-eroded and/or creep; 2- slip failure; 3- block failure)

Cut bank comments (eg. additional cut banks, protection condition, etc.):

DS

5

80

4

Is channel scour present? Thi ( $Y$ or if $N$ type ctrl-n cs) Mid-scour distance: $\underline{\mathbf{s} \text { is a }}$ Scour dimensions: Length bar Width at Depth: the Positioned do \% Scour comments (eg. additional scour areas, local scouring process, etc.): tream bridge face in the center of the channel.

Are there major confluences? $\mathbf{N}$ ( $Y$ or if $N$ type ctrl-n $m c)$

Confluence 1: Distance -

Confluence 2: Distance Enters on -

Enters on ( $L B$ or $R B$ ) (LB or $R B)$
How many? -

Type (1- perennial; 2- ephemeral)

Type (1-perennial; 2- ephemeral)

Confluence comments (eg. confluence name):

NO CUT BANKS

\section{F. Geomorphic Channel Assessment}

107. Stage of reach evolution

1- Constructed

2- Stable

3- Aggraded

4- Degraded

5- Laterally unstable

6- Vertically and laterally unstable 



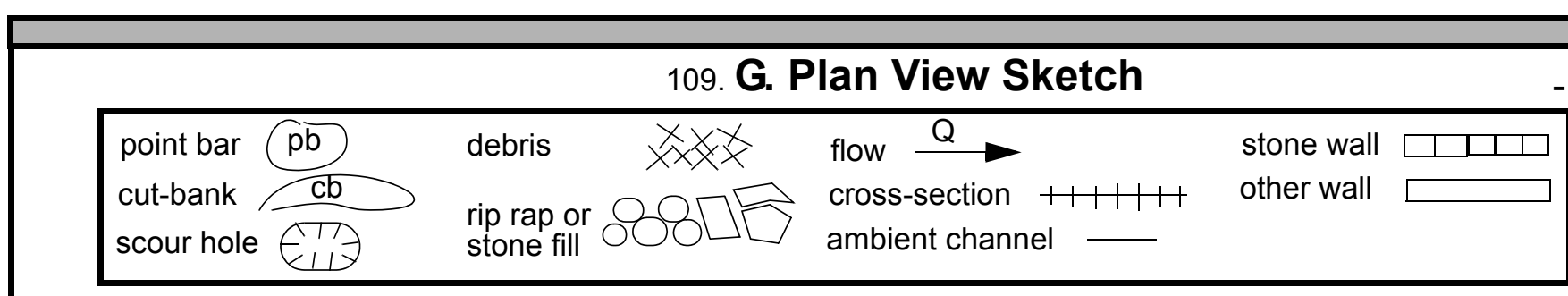


APPENDIX F:

SCOUR COMPUTATIONS 
SCOUR COMPUTATIONS

\begin{tabular}{|c|c|c|c|}
\hline $\begin{array}{ll}\text { Structure Number: CHELTH00460043 } \\
\text { Road Number: } & \text { TH46 }\end{array}$ & & $\begin{array}{l}\text { Town: } \\
\text { County: }\end{array}$ & $\begin{array}{l}\text { CHELSEA } \\
\text { ORANGE }\end{array}$ \\
\hline Stream: JAIL BROOK & & & \\
\hline Initials SAO & Checked: & ECW & \\
\hline alysis of contraction scour, live- & ed or $\mathrm{cl}$ & ear wat & \\
\hline Critical Velocity of Bed Material & converted & to Engl & sh units) \\
\hline (Richardson and others, 1995, p. 28 & , eq. 16) & & \\
\hline Approach Section & & & \\
\hline Characteristic & $100 \mathrm{yr}$ & $500 \mathrm{yr}$ & other $Q$ \\
\hline Total discharge, cfs & 920 & 1450 & 0 \\
\hline Main Channel Area, ft2 & 110 & 154 & 0 \\
\hline Left overbank area, ft2 & 0 & 0 & 0 \\
\hline Right overbank area, ft2 & 0 & 1 & 0 \\
\hline Top width main channel, ft & 23.4 & 28.6 & 0 \\
\hline Top width L overbank, ft & 0 & 0 & 0 \\
\hline Top width $\mathrm{R}$ overbank, ft & 0 & 1.4 & 0 \\
\hline D50 of channel, ft & 0.141 & 0.141 & 0 \\
\hline D50 left overbank, ft & -- & -- & - \\
\hline D50 right overbank, ft & -- & -- & -- \\
\hline Y1, average depth, $M C$, ft & 4.7 & 5.4 & $\mathrm{~N} / \mathrm{A}$ \\
\hline Y1, average depth, LOB, ft & $\mathrm{N} / \mathrm{A}$ & $\mathrm{N} / \mathrm{A}$ & $\mathrm{N} / \mathrm{A}$ \\
\hline $\mathrm{Y}_{1}$, average depth, ROB, ft & $\mathrm{N} / \mathrm{A}$ & 0.7 & $\mathrm{~N} / \mathrm{A}$ \\
\hline Total conveyance, approach & 6013 & 9312 & 0 \\
\hline Conveyance, main channel & 6013 & 9311 & 0 \\
\hline Conveyance, LOB & 0 & 0 & 0 \\
\hline Conveyance, ROB & 0 & 1 & 0 \\
\hline Percent discrepancy, conveyance & 0.0000 & 0.0000 & $\mathrm{~N} / \mathrm{A}$ \\
\hline Qm, discharge, MC, Cfs & 920.0 & 1449.8 & $\mathrm{~N} / \mathrm{A}$ \\
\hline Q1, discharge, LOB, Cfs & 0.0 & 0.0 & $\mathrm{~N} / \mathrm{A}$ \\
\hline Qr, discharge, ROB, cfs & 0.0 & 0.2 & $\mathrm{~N} / \mathrm{A}$ \\
\hline Vm, mean velocity $\mathrm{MC}$, ft/s & 8.4 & 9.4 & $\mathrm{~N} / \mathrm{A}$ \\
\hline $\mathrm{Vl}$, mean velocity, LOB, ft/s & $\mathrm{N} / \mathrm{A}$ & $\mathrm{N} / \mathrm{A}$ & $\mathrm{N} / \mathrm{A}$ \\
\hline Vr, mean velocity, ROB, ft/s & $\mathrm{N} / \mathrm{A}$ & 0.2 & $\mathrm{~N} / \mathrm{A}$ \\
\hline Vc-m, crit. velocity, $M C$, ft/s & 7.6 & 7.7 & $\mathrm{~N} / \mathrm{A}$ \\
\hline Vc-l, crit. velocity, LOB, ft/s & $\mathrm{N} / \mathrm{A}$ & $\mathrm{N} / \mathrm{A}$ & $\mathrm{N} / \mathrm{A}$ \\
\hline Vc-r, crit. velocity, ROB, ft/s & $\mathrm{N} / \mathrm{A}$ & $\mathrm{N} / \mathrm{A}$ & $\mathrm{N} / \mathrm{A}$ \\
\hline Results & & & \\
\hline Live-bed(1) or Clear-Water(0) Contr & action $\mathrm{Sc}$ & our? & \\
\hline Main Channel & 1 & 1 & $\mathrm{~N} / \mathrm{A}$ \\
\hline Left Overbank & $\mathrm{N} / \mathrm{A}$ & $\mathrm{N} / \mathrm{A}$ & $\mathrm{N} / \mathrm{A}$ \\
\hline Right Overbank & $\mathrm{N} / \mathrm{A}$ & $\mathrm{N} / \mathrm{A}$ & $\mathrm{N} / \mathrm{A}$ \\
\hline
\end{tabular}




\begin{tabular}{|c|c|c|c|c|c|c|}
\hline \multicolumn{7}{|c|}{$\begin{array}{l}\text { Laursen's Live Bed Contraction Scour } \\
\mathrm{y} 2 / \mathrm{Y} 1=(\mathrm{Q} 2 / \mathrm{Q} 1)^{\wedge}(6 / 7) *(\mathrm{~W} 1 / \mathrm{W} 2)^{\wedge}(\mathrm{k} 1) \\
\text { ys=y2-y_bridge } \\
(\text { Richardson and others, 1995, p. } 30, \text { eq. } 17 \text { and 18) }\end{array}$} \\
\hline & Approach & & & Bridge & & \\
\hline Characteristic & $100 \mathrm{yr}$ & $500 \mathrm{yr}$ & Other $Q$ & $100 \mathrm{yr}$ & $500 \mathrm{yr}$ & Other $Q$ \\
\hline Q1, discharge, cfs & 920 & 1450 & 0 & 920 & 1450 & 0 \\
\hline Total conveyance & 6013 & 9312 & 0 & 4945 & 7808 & 0 \\
\hline Main channel conveyance & 6013 & 9311 & 0 & 4945 & 7808 & 0 \\
\hline Main channel discharge & 920 & 1450 & $\mathrm{~N} / \mathrm{A}$ & 920 & 1450 & $\mathrm{~N} / \mathrm{A}$ \\
\hline Area - main channel, ft2 & 110 & 154 & 0 & 83.2 & 113 & 0 \\
\hline (W1) channel width, ft & 23.4 & 28.6 & 0 & 21.9 & 22.2 & 0 \\
\hline (Wp) cumulative pier width, ft & 0 & 0 & 0 & 0 & 0 & 0 \\
\hline w1, adjusted bottom width(ft) & 23.4 & 28.6 & 0 & 21.9 & 22.2 & 0 \\
\hline D50, ft & 0.141 & 0.141 & 0.141 & & & \\
\hline w, fall velocity, ft/s (p. 32) & 3.1 & 3.1 & 0 & & & \\
\hline y, ave. depth flow, ft & 4.70 & 5.38 & $\mathrm{~N} / \mathrm{A}$ & 3.80 & 5.09 & $\mathrm{~N} / \mathrm{A}$ \\
\hline S1, slope EGL & 0.041 & 0.049 & 0 & & & \\
\hline $\mathrm{P}$, wetted perimeter, $\mathrm{MC}$, ft & 30 & 36 & 0 & & & \\
\hline R, hydraulic Radius, ft & 3.667 & 4.278 & $\mathrm{~N} / \mathrm{A}$ & & & \\
\hline $\mathrm{V}^{*}$, shear velocity, ft/s & 2.200 & 2.598 & $\mathrm{~N} / \mathrm{A}$ & & & \\
\hline $\mathrm{V} * / \mathrm{w}$ & 0.710 & 0.838 & $\mathrm{~N} / \mathrm{A}$ & & & \\
\hline $\begin{array}{l}\text { Bed transport coeff., k1, (0.59 if } \\
\text { k1 }\end{array}$ & $\begin{array}{l}\mathrm{V} * / \mathrm{w}<0.5 \\
0.64\end{array}$ & $\begin{array}{l}0.64 \text { if } \\
0.64\end{array}$ & $\begin{array}{c}.5<\mathrm{V} * / \mathrm{W}<2 \\
0\end{array}$ & ; 0.69 if & $\mathrm{V} * / \mathrm{w}>2.0$ & 0 p. 33) \\
\hline $\mathrm{y}^{2}$, depth in contraction, ft & 4.90 & 6.33 & $\mathrm{~N} / \mathrm{A}$ & & & \\
\hline ys, scour depth, ft & 1.11 & 1.24 & $\mathrm{~N} / \mathrm{A}$ & & & \\
\hline
\end{tabular}

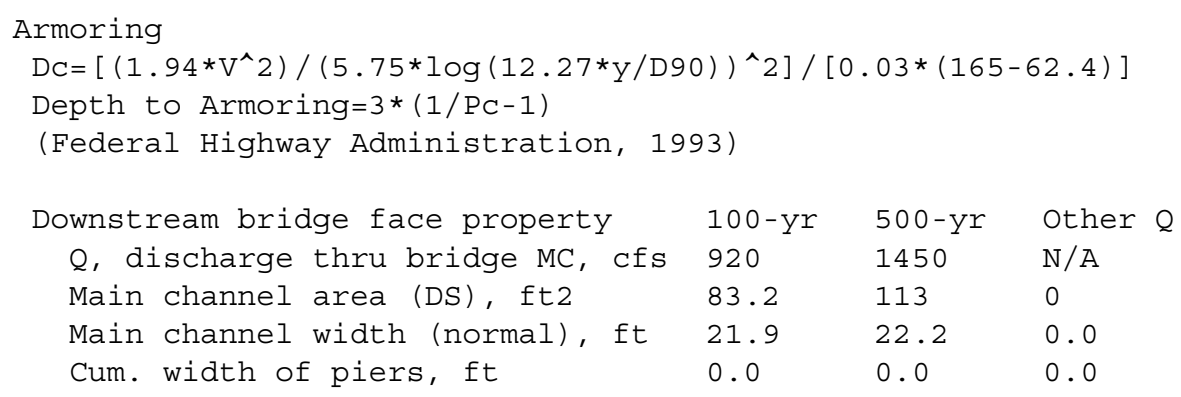




$\begin{array}{llll}\text { Adj. main channel width, ft } & 21.9 & 22.2 & 0.0 \\ \text { D90, ft } & 0.8560 & 0.8560 & 0.0000 \\ \text { D95, ft } & 1.1480 & 1.1480 & 0.0000 \\ \text { Dc, critical grain size, ft } & 0.7734 & 0.9043 & \text { N/A } \\ \text { PC, Decimal percent coarser than Dc } 0.113 & 0.091 & 0.000 \\ \text { Depth to armoring, ft } & & & \\ & & & \end{array}$

Abutment Scour

Froehlich's Abutment Scour

$\mathrm{Ys} / \mathrm{Y} 1=2.27 * \mathrm{~K} 1 * \mathrm{~K} 2 *\left(\mathrm{a}^{\prime} / \mathrm{Y} 1\right)^{\wedge} 0.43 * \mathrm{Fr} 1^{\wedge} 0.61+1$

(Richardson and others, 1995, p. 48, eq. 28)

Left Abutment Right Abutment

Characteristic

$100 \mathrm{yr} Q 500 \mathrm{yr} Q$ Other Q $100 \mathrm{yr}$ Q $500 \mathrm{yr} Q$ Other Q

\begin{tabular}{|c|c|c|c|c|c|}
\hline (Qt), total discharge, cfs & 920 & 1450 & 0 & 920 & 1450 \\
\hline abut.length blocking flow, ft & 0.8 & 2.7 & 0 & 0.7 & 5.1 \\
\hline area of blocked flow ft2 & 2.4 & 8.1 & 0 & 2 & 10.8 \\
\hline discharge blocked abu & 11.5 & 39.2 & 0 & 9.2 & 50 \\
\hline
\end{tabular}

(If using Qtotal_overbank to obtain Ve, leave Qe blank and enter Ve and Fr manually)

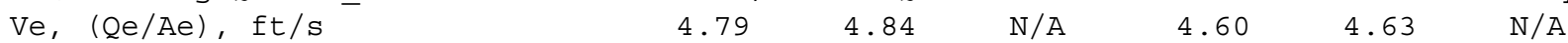

ya, depth of f/p flow, ft $\quad 3.00 \quad 3.00 \quad$ N/A $\quad 2.86 \quad 2.12 \quad$ N/A

--Coeff., Kl, for abut. type (1.0, verti.; 0.82, verti. w/ wingwall; 0.55, spillthru) $\mathrm{K} 1$

$\begin{array}{llllll}0.82 & 0.82 & 0.82 & 0.82 & 0.82 & 0.82\end{array}$

--Angle (theta) of embankment (<90 if abut. points DS; >90 if abut. points US)

$\begin{array}{lllllll}\text { theta } & 90 & 90 & 90 & 90 & 90 & 90\end{array}$

K2 $\begin{array}{rrrrrr}1.00 & 1.00 & 1.00 & 1.00 & 1.00 & 1.00\end{array}$

$\begin{array}{llllllll}\text { Fr, froude number f/p flow } & 0.488 & 0.492 & \text { N/A } & 0.480 & 0.561 & \text { N/A }\end{array}$

$\begin{array}{lllllll}\text { ys, scour depth, ft } & 5.04 & 6.46 & \text { N/A } & 4.71 & 6.16 & \text { N/A }\end{array}$

HIRE equation ( $\left.\mathrm{a}^{\prime} / \mathrm{ya}>25\right)$

$\mathrm{Ys}=4 * \mathrm{Fr}^{\wedge} 0.33 * \mathrm{Y} 1 * \mathrm{~K} / 0.55$

(Richardson and others, 1995, p. 49, eq. 29)

$a^{\prime}$ (abut length blocked, ft)

$0.8-2.7$

yl (depth $f / p$ flow, ft)

3.00

2.7

0

0.7

5.1

0

$a^{\prime} / y^{1}$

$0.27 \quad 0.90$

$\mathrm{N} / \mathrm{A}$

2.86

2.12

$\mathrm{N} / \mathrm{A}$

Skew correction (p. 49, fig. 16)

1.00

1.00

$\mathrm{N} / \mathrm{A}$

0.25

2.41

$\mathrm{N} / \mathrm{A}$

Froude no. f/p flow

0.49

0.49

$\mathrm{N} / \mathrm{A}$

1.00

1.00

1.00

Ys w/ corr. factor K1/0.55:

$\begin{array}{lllllll}\text { vertical } & \text { N/A } & \text { N/A } & \text { N/A } & \text { N/A } & \text { N/A } & \text { N/A } \\ \text { vertical w/ } \text { ww's }^{\prime} & \text { N/A } & \text { N/A } & \text { N/A } & \text { N/A } & \text { N/A } & \text { N/A }\end{array}$




\begin{tabular}{|c|c|c|c|c|c|c|}
\hline spill-through & $\mathrm{N} / \mathrm{A}$ & $\mathrm{N} / \mathrm{A}$ & $\mathrm{N} / \mathrm{A}$ & $\mathrm{N} / \mathrm{A}$ & $\mathrm{N} / \mathrm{A}$ & $\mathrm{N} / \mathrm{A}$ \\
\hline \multicolumn{7}{|l|}{ Abutment riprap Sizing } \\
\hline \multirow{2}{*}{\multicolumn{7}{|c|}{$\begin{array}{l}\text { Isbash Relationship } \\
\mathrm{D} 50=\mathrm{Y} * \mathrm{~K} * \mathrm{Fr} r^{\wedge} 2 /(\mathrm{SS}-1) \text { and } \mathrm{D} 50=\mathrm{Y} * \mathrm{~K} *\left(\mathrm{Fr} r^{\wedge} 2\right)^{\wedge} 0.14 /(\mathrm{Ss}-1) \\
\text { (Richardson and others, 1995, p112, eq. 81,82) }\end{array}$}} \\
\hline & & & & & & \\
\hline Downstream bridge face property & Q100 & Q500 & Other Q & Q100 & Q500 & Other Q \\
\hline Fr, Froude Number & 1 & 1 & 0 & 1 & 1 & 0 \\
\hline$y$, depth of flow in bridge, ft & 3.80 & 5.09 & 0.00 & 3.80 & 5.09 & 0.00 \\
\hline \multicolumn{7}{|c|}{ Median Stone Diameter for riprap at: left abutment } \\
\hline Fr< $=0.8$ (vertical abut.) & $\mathrm{N} / \mathrm{A}$ & $\mathrm{N} / \mathrm{A}$ & 0.00 & $\mathrm{~N} / \mathrm{A}$ & $\mathrm{N} / \mathrm{A}$ & 0.00 \\
\hline Fr>0.8 (vertical abut.) & 1.59 & 2.13 & $\mathrm{~N} / \mathrm{A}$ & 1.59 & 2.13 & $\mathrm{~N} / \mathrm{A}$ \\
\hline Fr $<=0.8 \quad$ (spillthrough abut.) & $\mathrm{N} / \mathrm{A}$ & $\mathrm{N} / \mathrm{A}$ & 0.00 & $\mathrm{~N} / \mathrm{A}$ & $\mathrm{N} / \mathrm{A}$ & 0.00 \\
\hline Fr>0.8 (spillthrough abut.) & 1.40 & 1.88 & $\mathrm{~N} / \mathrm{A}$ & 1.40 & 1.88 & $\mathrm{~N} / \mathrm{A}$ \\
\hline
\end{tabular}

